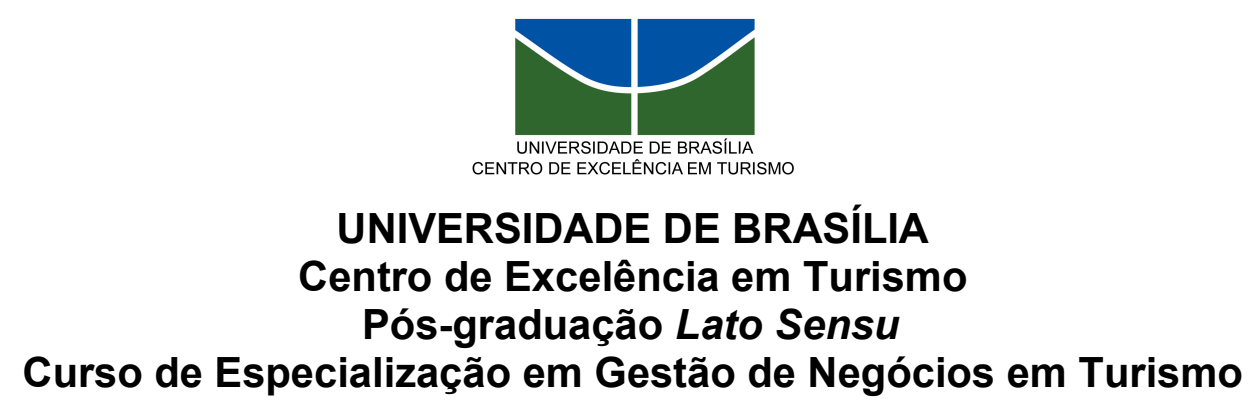

\title{
ANÁLISE DAS ESTRATÉGIAS PROMOCIONAIS DOS EMPREENDIMENTOS GASTRONÔMICOS COM FOCO NA ATIVIDADE TURÍSTICA EM BRASÍLIA
}

\author{
Camila Stella Faion \\ Professora orientadora Josivânia Silva Farias
}

Brasília - 2007 
UNIVERSIDADE DE BRASÍLIA

Centro de Excelência em Turismo

Pós-graduação Lato Sensu

Curso de Especialização em Gestão de Negócios em Turismo

\title{
ANÁLISE DAS ESTRATÉGIAS PROMOCIONAIS DOS EMPREENDIMENTOS GASTRONÔMICOS COM FOCO NA ATIVIDADE TURÍSTICA EM BRASÍLIA
}

\author{
Camila Stella Faion
}

Professora orientadora Josivânia Silva Farias

Monografia apresentada ao Centro de Excelência em Turismo - CET, da Universidade de Brasília - UNB, como requisito parcial à obtenção do grau de Especialista em Gestão de Negócios em Turismo 
Faion, Camila Stella.

Análise das estratégias promocionais dos empreendimentos gastronômicos com foco na atividade turística em Brasília / Camila Stella Faion.- Brasília, 2007.

Monografia (especialização) - Universidade de Brasília, Centro de Excelência em Turismo, 2007.

Orientador: Professora Josivânia Silva Farias.

1. Turismo. 2. Gastronomia. 3. Estratégias promocionais 


\title{
UNIVERSIDADE DE BRASÍLIA \\ Centro de Excelência em Turismo \\ Pós-graduação Lato Sensu
}

Curso de Especialização em Gestão de Negócios em Turismo

\author{
Camila Stella Faion
}

Aprovado por:

Professora orientadora: Josivânia Silva Farias

Professora: Wilma Araújo

Professora: Janine Colaço

Monografia apresentada ao Centro de Excelência em Turismo - CET, da Universidade de Brasília - UNB, como requisito parcial à obtenção do grau de Especialista em Gestão de Negócios em Turismo 


\section{DEDICATÓRIA}

Dedico este trabalho aos meus pais, José e Judith, que sempre estiveram ao meu lado durante minha formação.

Sem eles seria impossível chegar até aqui. Ao meu amado, Jailson, pela sua atenção, paciência e disponibilidade em ajudar. Ao meu Anjo da Guarda, pela sua proteção. 



\section{AGRADECIMENTO}

Agradeço a todos que estiveram ao meu lado durante esta caminha. A minha família que sempre me apoiou. Ao Jajá que nunca me desamparou.

Aos grandes amigos, Ana Carolina Silveira e Atair Costa, os quais nunca vou me esquecer. Obrigada pela ajuda.

Agradeço também ao corpo docente do Centro de Excelência em Turismo, os quais participaram do meu crescimento. A equipe da secretaria, Pedro e Luis, os quais nos apoiaram durante todo o curso.

Aos meus colegas de trabalho e amigos, Solange e Gabriel, agradeço pela paciência e o trabalho, o qual me ausentei em alguns momentos.

Finalmente, agradeço a professora Josivânia Silva farias, que me orientou durante a execução deste estudo, com excelência. 

EP ÍGRAFE

Bebida é água.

Comida é pasto.

Você tem sede de que?

Você tem fome de que?

A gente não quer só comida,

A gente quer comida, diversão e arte. 



\section{RESUMO}

O turismo é um dos setores da economia que mais cresce na atualidade em todo o mundo, e em Brasília, não é diferente: o turismo na cidade segue a tendência mundial. A gastronomia é um ramo que abrange a culinária, as bebidas, os materiais utilizados na alimentação e, em geral, todos os aspectos culturais a ela associados. A gastronomia interage com o turismo de diversas maneiras, ora como oferta, a qual torna-se produto turístico, ora no setor econômico, como gerador de renda e emprego. Os empreendimentos gastronômicos são os responsáveis pela produção de delícias e cultura que atraem a todos e, que impulsiona ambos os mercados. Brasília é considerada o terceiro pólo gastronômico do país. Quem vem a Brasília, dificilmente escapa de conhecer o aglomerado de empreendimentos gastronômicos destinados ao prazer de uma boa refeição. Com o advento da globalização e a popularização dos meios de comunicação, todos querem expandir o seu negócio e torna-lo conhecido. Considerando a importância da integração entre os setores de turismo e gastronomia, buscou-se saber qual a relação mantida entre eles em Brasília. As estratégias promocionais utilizadas pelos empreendimentos gastronômicos e a percepção de seus dirigentes considerando a atividade turística na cidade de Brasília, é o cerne dessa pesquisa. A pesquisa abrange aspectos como: tipo de estabelecimento, tempo de conhecimento no ramo da gastronomia, conhecimento dos proprietários e/ou gerentes da importância do setor para o aumento do volume de vendas, dentre outros fatores. Atualmente, a realidade é outra, além dos empreendimentos gastronômicos terem que manter sua qualidade e sua clientela local precisam expandir e manter sua clientela turística. Assim, pretendeu-se analisar os empreendimentos gastronômicos, relacionando-os com a atividade turística existente na cidade; identificar e propor a interação entre os setores, intensificando desta forma, a diversificado cultural existente em Brasília, a qual está sendo descoberta não só pela sua vocação política, mas também por suas atrações turísticas, muitas idealizadas pelos traços arquitetônicos de Oscar Niemeyer e Lúcio Costa, e sua gastronomia, proveniente da miscelânea dos imigrantes que vieram para sua construção e que permanecem até os dias atuais.

\section{Turismo 2. Gastronomia 3. Marketing}





\begin{abstract}
The tourism is one of the economy sectors, which has been rising nowadays around the world and it is not different in Brasília: the tourism in this city follows the world trends. The gastronomy is a branch that encloses cooking, drinking, the material used in feeding and generally all the cultural aspects which are associated to it. It interacts with the tourism in several ways, sometimes as an offer, which one became a tourist product, sometimes in the economic sector, as a source of income and job. The gastronomical enterprises are responsible for the production of delights and culture which attracts everyone and, stimulates both markets. Brasilia is considered the third gastronomical area of the country. Everyone who comes to Brasília hardly escapes from knowing the quantity of gastronomical enterprises destined to the pleasure of a good meal. With the globalization of the means of communication, everyone wants to expand her/his business and it has been becoming known. Considering the importance of the integration between the tourism and the sector of gastronomy, people tried to know what relation exists between them in Brasília. The promotional strategies used by the gastronomical enterprise and the perception of their controllers considering that the tourist activity in Brasília is the aim of this research. The research encloses aspects as: sort of establishment, time of knowledge in the branch of gastronomy, knowledge of owners and/or managers about the importance of the sector for the rising of sales. Currently, the reality is another. Besides the gastronomical enterprises have to keep their quality and their local clientele, they need to expand and keep their tourist clientele. Then it was intended to analyze the gastronomical enterprises, relating them to the tourist activity that exists in the city; identifying and proposing an interaction between the sectors, intensifying the variety of culture in Brasília, which has been being discovered not just by its political vocation, but also by its tourist attractions, which are idealized by the architecture of Oscar Niemeyer and Lúcio Costa, and its gastronomy, which is from the miscellany of immigrants who came for its building and remains here until now.
\end{abstract}

\title{
1. Tourism 2. Gastronomy 3. Marketing
}





\section{LISTA DE TABELAS}

Tabela 1 - Dados da localização dos empreendimentos gastronômicos...................................26

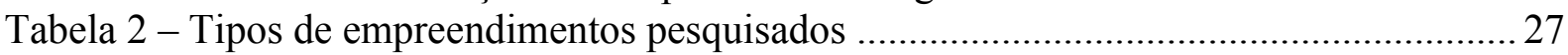

Tabela 3 - Tempo do empreendimento gastronômico no mercado..........................................27

Tabela 4 - Função do entrevistado no empreendimento gastronômico...................................27

Tabela 5 - Tempo de trabalho do entrevistado no setor de alimentação..................................28

Tabela 6 - A importância da marca do empreendimento gastronômico...................................28

Tabela 7 - Investimento com marketing pelo empreendimento gastronômico........................ 29

Tabela 8 - Justificativa de não investir em marketing........................................................ 29

Tabela 9 - As ações promocionais utilizadas pelos empreendimentos gastronômicos............30

Tabela 10 - Resultados esperados com as ações de marketing são alcançados........................31

Tabela 11 - Pesquisa de satisfação do cliente nos empreendimentos gastronômicos.............. 31

Tabela 12 - Como é realizada a pesquisa de satisfação do cliente........................................ 32

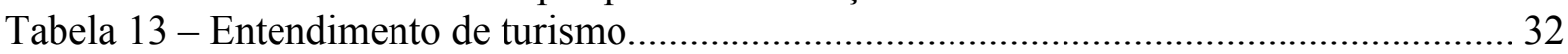

Tabela 14- Benefícios que o turismo proporciona à cidade............................................... 33

Tabela 15 - Lista de benefícios que o turismo proporcionam a cidade...................................34

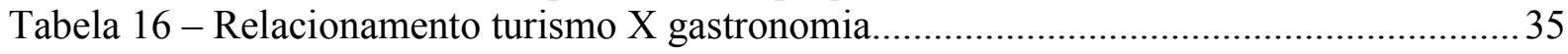

Tabela 17 - Turismo proporciona benefícios aos empreendimentos gastronômicos................ 35

Tabela 18 - Empreendimentos gastronômicos proporciona benefícios ao turismo...................36

Tabela 19 - Empreendimentos gastronômicos utilizam das atividades turísticas para se

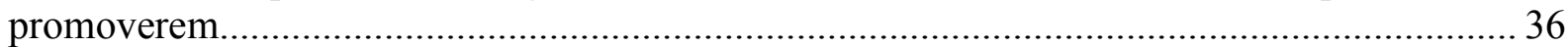

Tabela 20 - Participação no Festival gastronômico/ 2006.................................................. 37

Tabela 21 - Interesse do empreendimento gastronômico em promover-se junto as atividades turísticas 



\section{LISTA DE ABREVEATURAS E SIGLAS}

ABRASEL - Associação Brasileira de Bares e Restaurantes

BC\&VB - Brasília Convention \& Visitors Bureau

CODEPLAN - Companhia do Desenvolvimento do Planalto Central

EMBRATUR - Instituto Brasileiro de Turismo

IDH - Índice de Desenvolvimento Humano

OMT - Organização Mundial do Turismo

SEBRAE - Serviço Brasileiro de Apoio às Micros e Pequenas Empresas

SETUR - Secretaria de Estado e Turismo

UNESCO -Organizações das Nações Unidas para a Educação, a Ciência e a Cultura WTTC - World Travel \& Tourism Council 



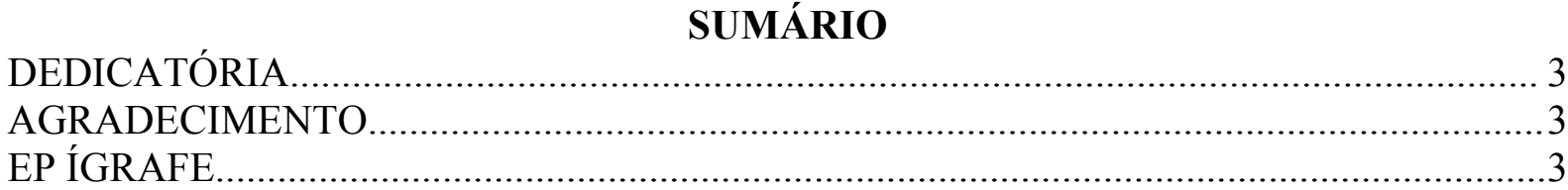

Bebida é água.

Comida é pasto.

Você tem sede de que?

Você tem fome de que?

A gente não quer só comida,

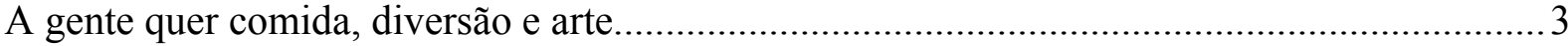

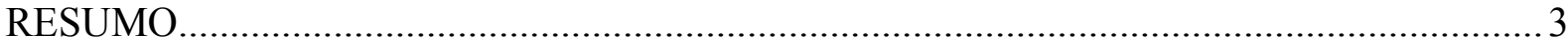

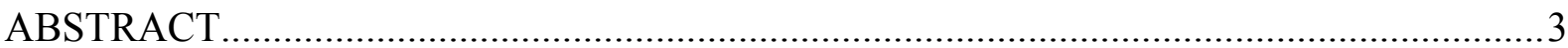

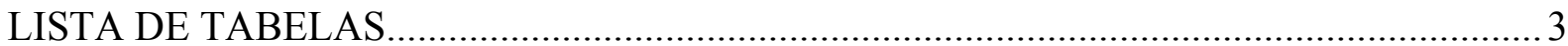

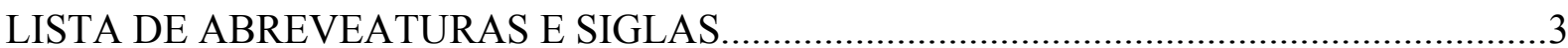

OMT - Organização Mundial do Turismo............................................................................... 3

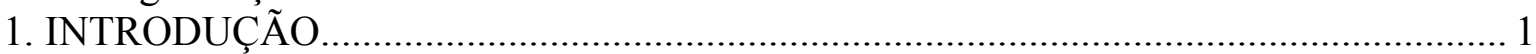

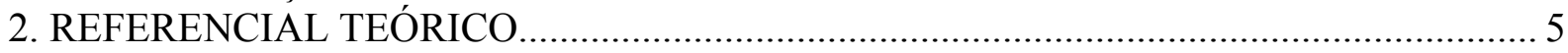

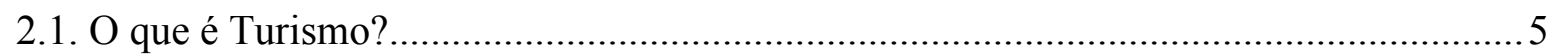

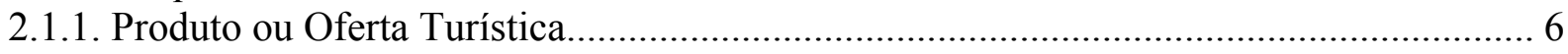

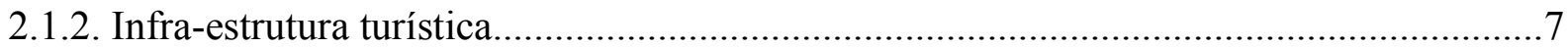

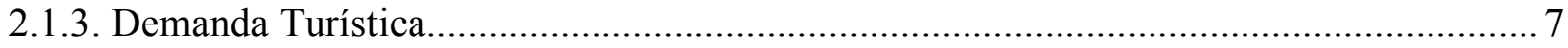

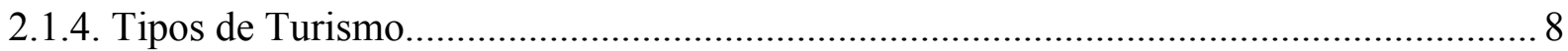

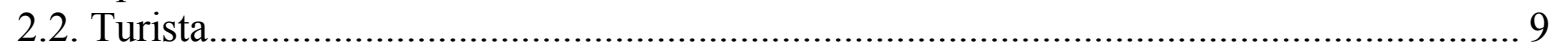

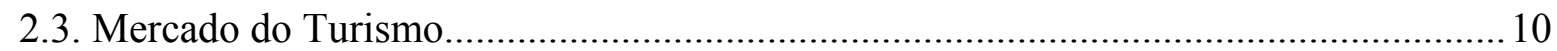

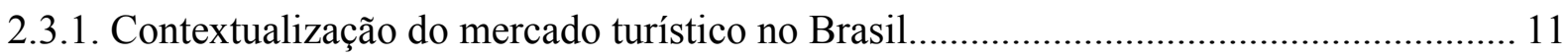

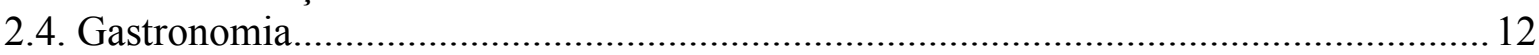

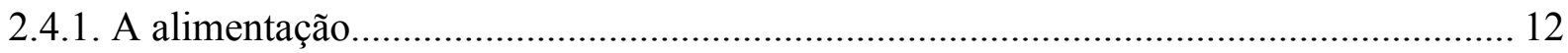

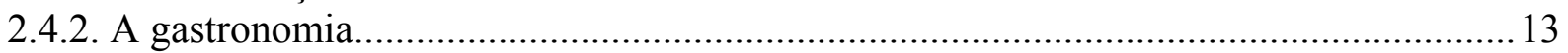

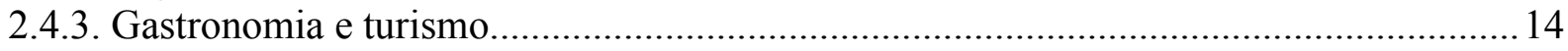

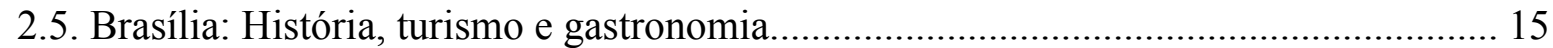

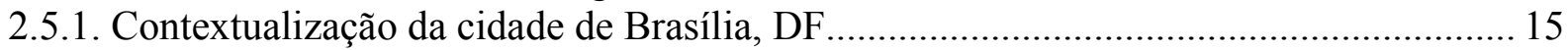

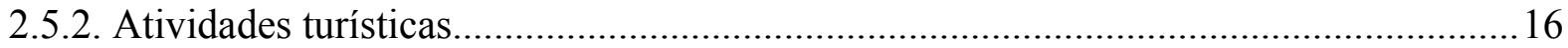

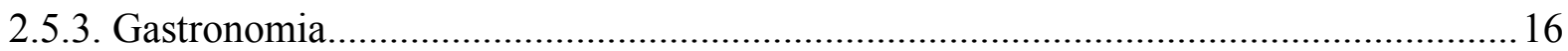

2.6. Marketing: Definição e ferramentas de marketing................................................... 17

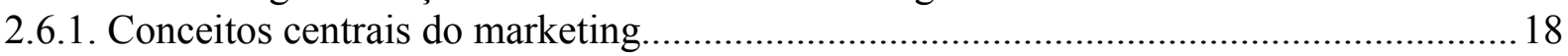

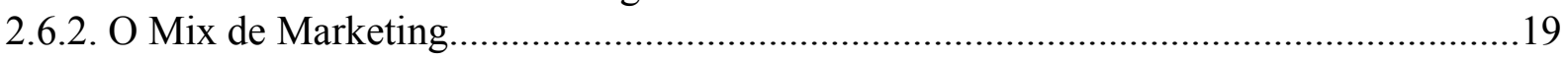

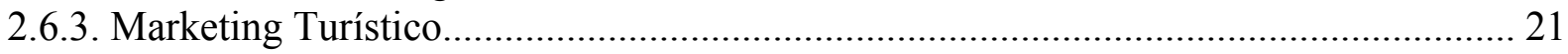

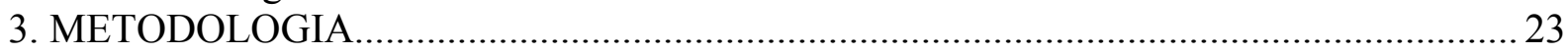

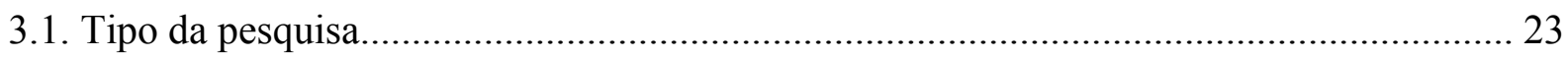

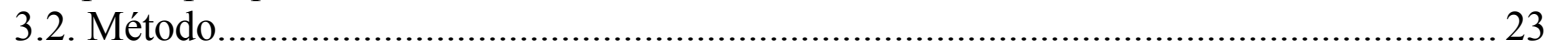

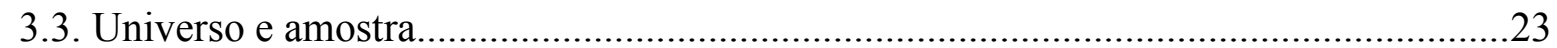

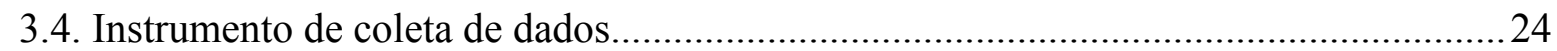

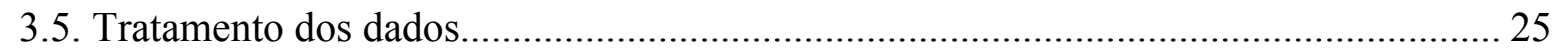

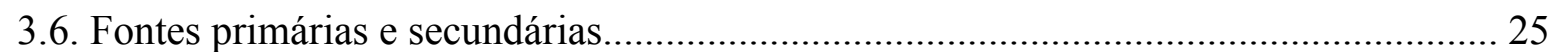

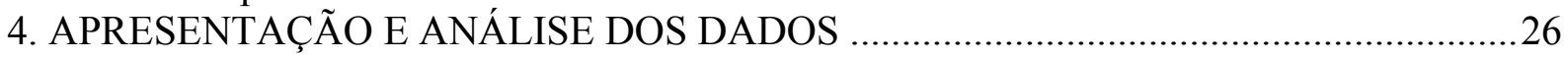

4.1. Localização dos empreendimentos gastronômicos....................................................26

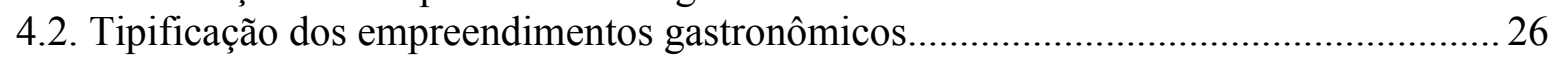

4.3. Tempo de mercado dos empreendimentos gastronômicos............................................ 27 
4.4. A função dos dirigentes dos empreendimentos gastronômicos.................................... 27

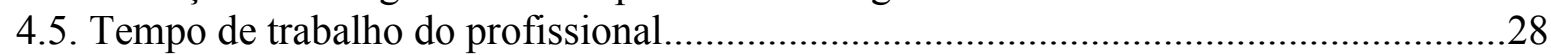

4.6. A importância da marca do empreendimento gastronômico........................................ 28

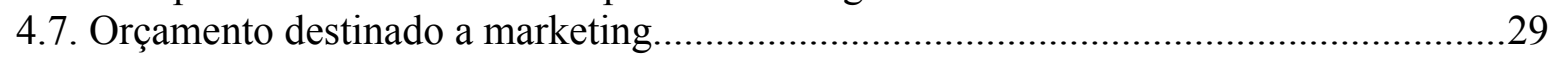

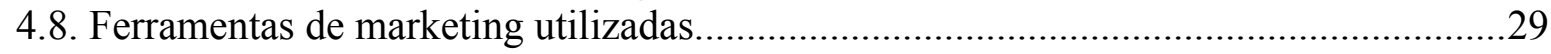

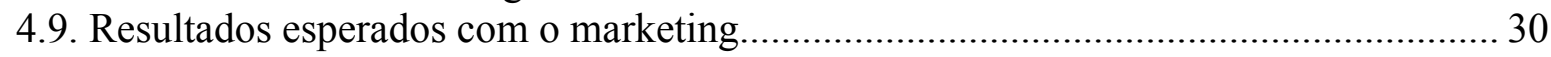

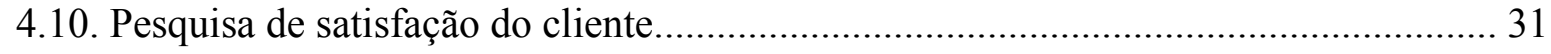

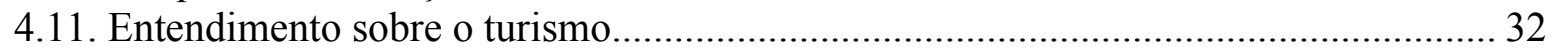

4.12. Benefícios que o turismo proporciona à cidade de Brasília.........................................33

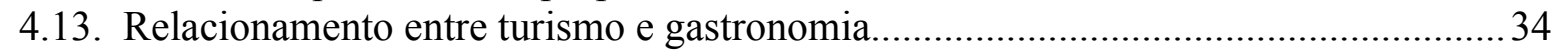

4.14. Benefícios que o turismo proporciona aos empreendimentos gastronômicos............. 35

4.15. Os benefícios que os empreendimentos gastronômicos proporcionam ao turismo..... 35

4.16. Promoção por meio das atividades turísticas............................................................... 36

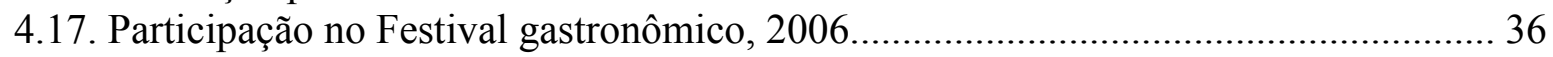

4.18. Interesse na promoção junto a atividades turísticas................................................... 37

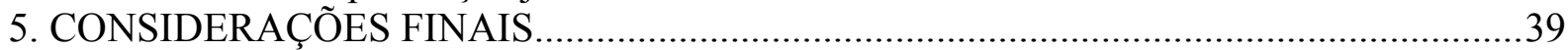

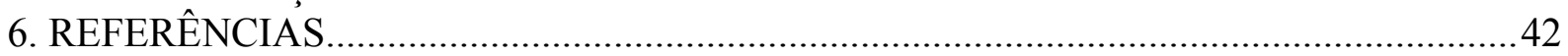

APÊNDICE A - Questionário de pesquisa de campo................................................... 44 


\section{INTRODUÇÃO}

O setor de Turismo vem obtendo destaque na economia mundial, principalmente por se tratar de um setor que abrange uma variedade de elementos materiais que formam o conjunto de requisitos para realizar a atividade turística, ou seja, formam o sistema turístico. Entre eles estão os meios de hospedagens, os transportes, as agências de viagens, os restaurantes e similares, os locais de entretenimento, entre outros.

Muitos destes empreendimentos participam diretamente do sistema turístico, como as agências de viagens. Outros são vistos como complementos para o sistema, como os empreendimentos gastronômicos, pois se tratam de empresas que se desenvolvem no local, independente da existência do turismo, mas que sem eles a atividade turística não poderia ser realizada.

Este estudo preocupou-se com um dos empreendimentos considerados complementares, os empreendimentos gastronômicos, que participa de forma integrada com turismo, seja culturalmente, como atrativo turístico propriamente dito, seja economicamente, como o maior empregador do setor de turismo (ABRASEL, 2004).

A gastronomia é, por si só, um produto turístico, pois faz parte da manifestação cultural de um povo. Quando se fala de cultura e identidade de um local, a gastronomia está sempre presente, pois ela é considerada patrimônio intangível pela Unesco, juntamente com outras obras culturais que trazem consigo a tradição de um povo (SCHLUTER, 2003, p.10).

A produção em escala dos alimentos fez com que lugares próprios para isso fossem criados, a fim de levar ao conhecimento de todos as delicias de todo o mundo. Assim empreendimentos gastronômicos foram surgindo, cada um na sua especialidade, no seu tipo de serviço.

O crescimento da atividade turística, juntamente com o aglomerado de empreendimentos gastronômicos destinados ao prazer de uma boa refeição em Brasília, fez com que a cidade fosse escolhida para o presente estudo, com o intuito de enfatizar a relação entre turismo e gastronomia.

Em Brasília são encontrados inúmeros empreendimentos gastronômicos caracterizado pela sua diversidade, já que se trata de um local no qual hábitos e tradições fundiram-se formando o que hoje conhecemos como cultura "candango", nome dado aos migrantes de várias regiões do país que vieram construir a cidade e acabaram estabelecendo-se (FISBERG, 2002, p.9). 
Diversas atividades turísticas são oferecidas na cidade, que também é considerada o terceiro pólo gastronômico do país, o que mostra a importância de compreender o trabalho dos empreendimentos gastronômicos no setor de turismo.

Estudar e analisar as ações promocionais dos empreendimentos gastronômicos traduz em conhecer qual o segmento (turistas ou residentes) essas ações atingem. Procurou-se compreender a gestão de seus dirigentes em relação à atividade turística existente na cidade, com o intuito de estruturar ações promocionais que integram estes segmentos que estão interrelacionadas, mas que, em alguns casos, não aproveitam desta oportunidade para desenvolverse.

Embora percebida que ações promocionais podem ser implementadas com foco na integração dos empreendimentos gastronômicos no setor turístico, resta-se saber qual a percepção dos dirigentes destes empreendimentos em promover seus produtos e serviços juntamente com as atividades turísticas da cidade de Brasília.

Assim, este trabalho teve o propósito de analisar as ações promocionais dos empreendimentos gastronômicos em Brasília, considerando a percepção dos seus dirigentes com relação ao setor de turismo.

A importância do estudo está em analisar a relação do setor de alimentação, com o turismo, de forma integrada. A conscientização do mercado local, a evolução desta parceria, o crescimento mútuo dos setores correspondentes, foi à oportunidade visada para o desenvolvimento deste trabalho.

Além do mercado, notou-se que os estudos do assunto na área acadêmica é de grande relevância, pois com o crescimento do turismo, é necessário a realização de pesquisas em todo seu âmbito, a fim de identificar suas ofertas, demandas, oportunidades, etc.

A viabilidade desta pesquisa, no entanto, só foi possível com a participação dos gestores dos empreendimentos gastronômicos da cidade no que tange a informação e detalhamentos do setor, da população de forma qualitativa e do estudo teórico sobre a situação citada.

A questão do presente trabalho é enfática na área promocional dos empreendimentos gastronômicos em relação ao setor de turismo.

Verificar as estratégias promocionais e a percepção dos dirigentes dos empreendimentos gastronômicos de Brasília, DF, em relação ao setor de turismo é o objetivo geral perseguido nesta monografia. 
No entanto, para que o objetivo geral almejado fosse devidamente alcançado, fez-se necessário especificamente:

- Explicar, por meio da teoria, a relação entre o turismo e a gastronomia;

- Descrever o que é produto turístico e como a gastronomia está inserida neste contexto;

- Buscar dados sócio-econômicos do papel dos empreendimentos gastronômicos no setor de turismo em Brasília, DF;

- Indicar as estratégias de promoção utilizadas pelos empreendimentos gastronômicos da cidade;

- Verificar a existência de estratégias promocionais utilizadas pelos empreendimentos gastronômicos, direcionadas a atividade turística;

- Identificar a percepção dos dirigentes dos empreendimentos gastronômicos em relação ao seu envolvimento com o turismo;

Propor estratégias de promoção para os empreendimentos gastronômicos por meio das atividades turísticas existentes.

Trata-se de um estudo descritivo e analítico sobre as ações promocionais e a percepção dos dirigentes dos empreendimentos gastronômicos, em relação ao setor de turismo. O método utilizado foi o levantamento e a amostragem.

O universo da pesquisa foi baseado na revista Veja - Melhores da cidade 2006/ 2007, totalizando 444 empreendimentos gastronômicos. A amostra é não probabilística, sendo assim, definida por meio da conveniência e julgamento do pesquisador, totalizando 30 empreendimentos pesquisados.

A coleta de dados deu-se por meio de um questionário semi-estruturado, com questões abertas e fechadas, aplicado entre os dias 26 de fevereiro e 09 de março. Para o tratamento dos dados foram utilizadas ferramentas da estatística descritiva, por meio do uso do software SPSS.

Esta monografia é composta de referencial teórico, metodologia, analise e apresentação dos dados e resultados e de considerações finais.

O referencial teórico destaca os conceitos de turismo, seus produtos, ofertas e demanda. A importância da infra-estrutura básica e turística na localidade também é tratada neste capítulo, como fator de desenvolvimento da atividade. No tópico, tipos de turismo, são citados, sucintamente, alguns segmentos existentes no setor. O mercado do turismo reproduz 
a importância do setor de turismo na economia mundial e do Brasil, evidenciando seu crescimento, gerando renda e postos de trabalho. A definição de turista é apresentada, afim de distinguir o visitante, o turista potencial e o turista real.

Ainda no referencial teórico são considerados o conceito de gastronomia e seu relacionamento com a atividade turística. O papel cultural e econômico da gastronomia no setor de turismo é evidenciado no texto, com o intuito de demonstrar a importância do estudo que está sendo realizado.

A cidade de Brasília é apresenta com a história de sua fundação e informações gerais, turísticas e gastronômicas, considerando os aspectos da miscelânea de culturas existentes na cidade.

O marketing é o último item a ser apresentado no referencial teórico, destacando seu conceito e ferramentas, principalmente no setor de turismo.

A metodologia é o terceiro capítulo a ser apresentado, no qual são apresentados o tipo da pesquisa, os métodos utilizados, o universo e a amostra, o instrumento da coleta de dados e por fim o tratamento dos dados.

No capítulo destinado a analise e apresentação dos dados e resultados, são encontradas as informações da pesquisa realizada, por meio de tabelas e gráficos que apresentam os dados provenientes dos questionários respondidos pelos os dirigentes dos empreendimentos gastronômicos, bem como dados cruzados pelo pesquisar, no qual auxiliaram na obtenção dos resultados da pesquisa.

As considerações finais trata-se do último capitulo apresentado, no qual são apresentados as conclusões de pesquisa. 


\section{REFERENCIAL TEÓRICO}

O referencial teórico apresenta os conceitos essenciais ao estudo, tais como: o conceito de turismo e de termos que fazem parte deste setor, para devida compreensão do mercado que se buscar explorar no trabalho. O conceito de gastronomia e a abordagem de sua relação com o turismo contextualizam o objetivo antes citado.

\subsection{O que é Turismo?}

O termo turismo é tão complexo que a primeira discussão entre os autores já se faz em torno da origem da palavra. Para Andrade (1995, p.29), o termo se originou da palavra francesa tourisme, porém, ele mesmo acredita ser prudente abrir espaços para novas considerações.

Já Oliveira (2001, p.17) faz um questionamento mais profundo. Segundo ele, estudiosos do setor, como o suíço Arthur Haulot, apresentam a possibilidade da palavra turismo ter origem hebréia e ser originada da palavra tur, que corresponde ao conceito de viagem de descoberta, de exploração de reconhecimento.

Não há uma definição única do que seja turismo, ela se transforma de acordo com as necessidades humanas, assim sua definição torna-se dinâmica e surge de acordo com o comportamento sócio-cultural e econômico da humanidade (OTTO, 2001, p.19).

Para Barreto (1999, p.9), a primeira definição de turismo, provavelmente, tenha sido fornecida pelo economista austríaco Hermann Von Schullern, em 1911, para quem: "Turismo é o conceito que compreende todos os processos, especialmente os econômicos, que se manifestam na chegada, na permanência e na saída do turista de um determinado município, estado ou país".

A Organização Mundial de Turismo (OMT)/ Nações Unidas define turismo "como sendo um fenômeno que ocorre quando um ou mais indivíduos se transladam a um ou mais locais diferentes de sua residência habitual por um período maior que 24 horas e menor que 180 dias, sem participar dos mercados de trabalho e capital dos locais visitados" (conceito extraído do livro Turismo e Desenvolvimento - Planejamento e Organização, de OLIVEIRA, 2001, p.35).

O turismo é um dos modos de se aproveitar o lazer (COOPER, 2001, p.44). Fazer turismo não consiste só na viagem, é muito mais que isso, é descobrir tudo o que é interessante e, principalmente tudo que é diferente daquilo que está presente no cotidiano, a fazer, ouvir, ver, comer, etc. É descobrir o que cada local tem de especial, vivenciando a cultura, as festas e costumes da comunidade local. 
O setor de turismo envolve uma mistura de elementos materiais, que são os transportes, os alojamentos, as atrações e as diversões disponíveis. Os fatores psicológicos, que seriam desde uma simples fuga, passando pela concretização de um sonho ou fantasia, até simplesmente a recreação, o descanso. Deve-se incluir também os interesses sociais, históricos, culturais e econômicos.

Turismo é negócio, geração de renda e empregos diretos e indiretos, além de promover a interação e aproximação de pessoas de culturas e locais diferentes. Trata-se de uma atividade econômica que pertence ao setor terciário e é composto de um conjunto de serviços (meios de hospedagem, transporte, gastronomia, entretenimento, entre outros) que se vendem aos turistas.

Devido a seu desenvolvimento e maior acessibilidade, cada vez mais pessoas em todo mundo encontram nas viagens a melhor alternativa para preencher seu tempo livre, proporcionando assim as boas perspectivas para o turismo.

\subsubsection{Produto ou Oferta Turística}

A oferta, na economia, é definida como as várias quantidades possíveis de bens e serviços econômicos que os empresários estão aptos e dispostos a colocar no mercado sob determinadas condições de preço e por um espaço de tempo (CAMPOS E GONÇALVES, 1998, P.26).

De acordo com Ministério do Turismo (conceito extraído do site Turismo Informativo, 2004), produto turístico é o conjunto de atrativos, equipamentos e serviços turísticos, acrescidos de facilidades, afetado de forma organizada por um determinado preço. Assim, rotas, roteiros, destinos, etc, podem ser constituir em produto turístico.

Podemos sintetizar esta definição com Campos e Gonçalves (1998, p.26) que define a oferta ou produto turístico como o conjunto de atrações naturais e artificiais. As atrações naturais são o clima, a praia, cachoeiras, florestas, fauna, fontes temáticas, entre outros. As atrações artificiais compreendem os bens (teatros, monumentos, etc) e acontecimentos (carnaval, folclore, etc).

No entanto, para haver produto turístico de qualidade, é necessário promover a melhoria dos recursos existentes, tornando-os mais atraentes. 
O levantamento da oferta turístico é realizado pela EMBRATUR, e é classificado em três componentes: o levantamento dos atrativos turísticos; o levantamento dos equipamentos turísticos e; o levantamento da infra-estrutura de apoio à atividade turística.

\subsubsection{Infra-estrutura turística}

Toda a cidade que pretende se transformar em pólo turístico precisa disponibilizar uma série de produtos e serviços para atender as necessidades dos turistas, que exigem no mínimo conforto quando saem de casa.

A infra-estrutura engloba vários serviços, que acabam atendendo tantos os turistas com o os moradores da região, sendo que há cinco setores principais que estão diretamente relacionados com o turismo, que são (MIDDLETON, 2002, p.12):

- $\quad$ setores de acomodação;

- $\quad$ setor de atrações;

- $\quad$ setor de transportes;

- $\quad$ setor de organizadores de viagens;

- setor de organizadores do destino.

Deve-se lembrar que a infra-estrutura básica, como acesso, saneamento, energia, etc, de uma localidade também é elemento fundamental para a viabilização da atividade turística.

\subsubsection{Demanda Turística}

A definição de demanda turística é variável, pois depende da visão de cada autor. Por exemplo, os economistas definem a demanda como a relação entre ela e o preço e outras variáveis econômicas. Os geógrafos vão além do preço, eles incluem as pessoas que participam ou querem participar da atividade. Já os psicólogos definem a demanda a partir da motivação do turista (COOPER, 2001, p.56).

De acordo com Campos e Gonçalves (1998, p.28) a demanda turística pode ser classificada em:

- Demanda potencial: correspondente ao número de pessoas que possui tempo, renda, vontade de viajar, ou seja, potencial para realizar uma viagem.

- Demanda real: são as pessoas que realmente viajam para certo local. 
Cooper (2001, p.56) complementa que a demanda turística consiste de vários componentes, e que além dos dois citados acima, há também a classificação "sem demanda", que consiste nas pessoas que não desejam viajar.

De acordo com Cooper (2001, p.72), quando a pessoa toma a decisão de viajar, a capacidade de fazer a viagem e a natureza da viagem são determinadas por um grande número de fatores inter-relacionados, que podem ser divididos em dois grupos:

- estilo de vida: que inclui renda, emprego, direito a férias, grau de instrução e mobilidade;

- ciclo de vida: no qual a idade e as circunstâncias doméstica afetam tanto a quantidade quanto o tipo de turismo demandado.

Entender o comportamento do turista é necessário para que se possa tomar ciência (COOPER, 2001, p.63):

- das necessidades, dos motivos para a aquisição e do processo de decisão ao consumo do turismo;

- do impacto dos diversos efeitos das várias táticas promocionais;

- da possível percepção do risco em aquisições turísticas;

- dos diferentes segmentos de mercado baseados no comportamento de compra;

- de como os administradores poderão melhorar suas chances de sucesso em marketing.

\subsubsection{Tipos de Turismo}

São vários os segmentos do turismo que encontramos atualmente, devido as diferentes motivações das pessoas e os diversos recursos que as localidades exploram e desenvolvem.

De acordo com Otto(2001, p.31), certos tipos de turismo se desenvolvem mais em certas regiões do que em outras. Pode-se dizer que isto é influenciado pelo mesmo motivos que o segmenta. Cita-se alguns tipos de turismo:

- Turismo lúdico: Consiste em atividades de jogos, com uma estrutura completa e organizada para receber os apostadores. Exemplo: Las Vegas;

- Turismo cultural: Pode-se dizer que este tipo de turismo é caracterizado pelo conjunto de valores de um local, assim toda pessoa que realiza uma viagem, poderia elevar o 
fator cultural. Mas não é isso, o turismo cultural envolve os turistas que tem uma especial inclinação por atividade culturais, artísticas e educacionais;

- Turismo de compra: São as pessoas que viajam pelo motivo de percorrer os centros comerciais e realizar compras;

- Turismo gastronômico: este tipo de turismo pode estar incluso no turismo cultural, a principal diferença entre eles é a motivação do turista, que consiste conhecer a gastronomia de uma localidade;

- Turismo de saúde: Este tipo de turismo é praticado há milênios. São praticadas por pessoas que buscam tratamento de saúde, estéticas, terapias, massagens, programas pra emagrecimento e desintoxicação;

- Turismo de natureza: Consiste na prática do nudismo e respeito à natureza;

- Turismo ecológico: este tipo de turismo vem ganho espaço a cada ano. A principal motivação é observar a importância da vida em harmonia com a natureza. É uma prática seletiva, restrita a algumas regiões do planeta;

- Turismo religioso: Consiste na prática de atividades relacionadas a fé e a visitação a lugares ditos sagrados;

- Turismo rural: Consiste no conjunto de atividades desenvolvidas no meio rural, comprometido com a produção agropecuária, agregando valor a produtos e serviços;

- Turismo de negócios: Segmento mais promissor na atualidade. Consiste em viagens motivas por congressos, reuniões de negócios. Geralmente realizadas através de empresas, corporações;

- Turismo místico: Consiste em desfrutar regiões místicas que envolvem fé, sensibilidade e conhecimento.

Logicamente a outros tipos de turismo que completam o setor, mas não faz parte deste estudo adentrar neste assunto.

\subsection{Turista}

São vários termos que se utiliza para nomear a pessoa que faz turismo. Para melhor entendimento, considera-se: 
- Visitante, é quem visita um local diferente daquele que reside. "O intuito da viagem pode ser qualquer um, férias, visita a amigos e parentes, até mesmo de caráter profissional ou a integração do lazer com o profissional, desde que não receba nada por isso" (OLIVEIRA, 2001, p.37).

- O turista é o ator do turismo (COOPER, 2001, p.38). É um visitante que se desloca voluntariamente para um local diferente da sua residência e do seu trabalho, não motivado pela obtenção de lucro, por um período de tempo igual ou superior a vinte e quatro horas.

Como citado por Cooper (2001, p.45), pode-se classificar os turistas em duas formas básicas de acordo com a natureza de sua viagem:

- Primeiro, classificar os turistas em domésticos e internacionais;

- Segundo, classificar pela categoria ou propósito da viagem, que podem ser: por lazer e recreação; outros propósitos de turismo; profissional e de negócio.

Esta classificação auxilia na busca de dados para fim estatísticos e também no planejamento de marketing do turismo.

Cooper (2001, p.47) complementa que há muitas formas de classificar o turista por meio das variáveis econômicas (ocupação, renda, etc) e variáveis da viagem (período de viagem, distância, despesa, duração, etc).

Deve-se lembrar que pessoas que viajam por um período menor que vinte quatro horas é chamado de excursionista.

\subsection{Mercado do Turismo}

Viagens e turismo significam trabalho. Estudos mostram que mais de 500 milhões de pessoas estarão trabalhando no setor de turismo até o fim desta década. Mais que postos de trabalhos, o setor significa prestação de serviço, a porta de entrada para o progresso da economia nacional e local, no qual a perspectiva é de promover a qualidade de vida das pessoas ao redor do mundo (Blueprint of new tourism, WTTC, 2003).

Sabe-se que hoje a indústria do turismo é uma das que mais têm se desenvolvido no mundo, gerando empregos e tornando-se a principal fonte de arrecadação de muitos países.

De acordo com Wille da Revista do Turismo, na Europa é visto que, o turismo é encarado com seriedade e planejamento, com isto, países como a Espanha, Portugal e França, vêm se 
destacando cada vez mais neste setor. No entanto, para países subdesenvolvidos ou em desenvolvimento, como o Vietnã e a África do Sul, por exemplo, o turismo tem se mostrado como alternativa para o fortalecimento econômico.

O turismo está entre as primeiras posições como setor mais lucrativo da economia, oscilando entre o segundo e terceiro setor de maior movimentação econômica em escala mundial. Segundo a Organização Mundial do Turismo, o setor emprega 250 milhões de pessoas em todo planeta, e é o maior gerador de receitas de impostos, equivalendo a US\$ 802 bilhões. (EMBRATUR).

\subsubsection{Contextualização do mercado turístico no Brasil}

Norton Luiz Lenhart em entrevista ao jornal do Comércio, diz que o Brasil é visto pela Organização Mundial do Turismo (OMT) como um país de um futuro muito promissor para o turismo. A organização acredita, que em 10 anos, o país deverá ser um dos principais destinos turísticos do mundo por diversos fatores, como a diversidade cultural e a variedade de produtos.

No Brasil, a atividade turística vem apresentando um crescimento bastante expressivo para a economia. De acordo com Norton Luiz Lenhart, o turismo deve encerrar 2006 com a geração de US\$5 bilhões em receitas cambiais. No mundo o valor deve ser de US\$ 800 bilhões (Jornal do Comércio, 2006).

Na entrevista ao Jornal Gazeta Mercantil (2006), Márcio Favilla secretário executivo do Ministério do Turismo, diz que sessenta e cinco milhões de brasileiros viajam dentro do país, sendo que vinte e um milhões só viajam uma vez ao ano, outros vinte e um milhões fazem duas viagens ao ano e vinte e oito milhões fazem seis viagens por ano. "São duzentos e vinte e cinco milhões de viagens, das quais sessenta e sete milhões são em âmbito nacional, cinqüenta e quatro milhões em âmbito regional e cento e quatro milhões em âmbito estadual", informa Favilla.

Ele completa, que a demonstração de que o Governo Federal está priorizando o turismo é visto por meio da execução orçamentária, que passou de $\mathrm{R} \$ 127$ mil em 2003, para R $\$ 1,026$ bilhão entre janeiro e agosto deste ano (2006), que corresponde a noventa e cinco por cento do previsto. A idéia, se possível, é ampliar o valor para 2007.(JORNAL GAZETA MERCANTIL, 2006).

De acordo com a Pesquisa Anual de Conjuntura da Fundação Getúlio Vargas, as 80 maiores empresas de turismo do turismo registraram o ano passado receita total de $\mathrm{R} \$ 25,5$ bilhões, 
crescimento de $17,27 \%$ em relação a 2004. "Isto se deve a ampliação de roteiros", confirma Favilla (JORNAL GAZETA MERCANTIL, 2006).

\subsection{Gastronomia}

\subsubsection{A alimentação}

"A satisfação das necessidades alimentares é condição indispensável para a manutenção da vida" (CASTROGIOVANNI, AZAMBUJA, 2001, p.69).

Junto à evolução do homem, a alimentação também se desenvolveu. No início o homem partiu para caça e colheita, logo, aprendeu a cultivar as plantas, a criar os animais. Cozinhar os alimentos fez parte do processo da evolução, no qual o ser humano é capaz de transformar os alimentos.

A alimentação é um processo consciente e voluntário no ser humano, estabelecido de acordo com a cultura que está inserida. Sendo assim, o conceito de alimentação implica tantos os processos nutritivos, como o marco cultural e social dos povos (SCHLUTER, 2003, p.13).

Pode-se utilizar a teoria de Maslow para analisar os hábitos alimentares, da mesma forma que as motivações turísticas (SCHLUTER, 2003, p.22,23) como:

- Satisfação das necessidades básicas: etapa básica, relacionada à aquisição de alimentos para sobrevivência;

- Necessidade de segurança: relacionada a armazenar comida para o futuro;

- Necessidade de pertinência: relacionada à comida que indica fazer parte de um grupo;

- Status: relacionados alimentos que se associam a determinadas classes sociais;

- Auto-realização: relacionada as pessoas que tendem a experimentar pratos exóticos e diferentes.

A mesa é considerada o centro das relações quando se fala em alimentação. Todos reúnem ao seu redor, dando sentido de organização, novidades, alegria, família. Causa o efeito de socialização, de conjunto, fortalecendo os relacionamentos sociais, informa Coelho (2005, p.15).

De acordo com Azambuja (2001, p.72), “ao comer, o homem se despe de muitas máscaras, se exterioriza, exercendo, de certo modo, sua posição na sociedade”. 


\subsubsection{A gastronomia}

A gastronomia é um ramo que abrange a culinária, as bebidas, os materiais utilizados na alimentação e, em geral, todos os aspectos culturais a ela associados.

Schluter (2003, p.27), cita a gastronomia em seu livro:

"Diferentes autores afirmam que a gastronomia de uma sociedade e constitui uma linguagem mediante a qual está expressa sua estrutura de maneira inconsciente. Geralmente as sociedades utilizam para preparar seus pratos elementos que se desenvolvem bem na área em que residem e que polarizam a afetividade e o enfoque simbólico, dando origem em certas ocasiões, a uma verdadeira cultura".

Coelho (2005, p.15) define gastronomia como, "a história cultural da alimentação", no qual sua essência baseia na mudança, temporalidade, a visão de passado como processo contínuo de tendências.

"A cultura e a história de um povo, ou de uma região, se expressam de diversas formas. Umas delas, com certeza, é a gastronomia" (PINTO J., 2005, p.5).

Quando se fala de churrasco, logo lembramos do Sul, o queijo minas faz lembra-se Minas Gerais, já os deliciosos chocolates suíços, logicamente nos remete aos Alpes. Assim, também é com as bebidas, ao falar de whisky a referencia é a Escócia. A cultura é permanente, é viva.

A UNESCO, em 1977, inseriu um novo conceito, o de patrimônio intangível, no qual a gastronomia está inserida. Neste caso, receitas tradicionais são consideradas tão valiosas quantos os monumentos de uma localidade. O mate, no Brasil, é considerado patrimônio gastronômico nacional (SCHLUTER, 2003, p.10, 41).

$\mathrm{Na}$ era da globalização, cozinhas tradicionais se mantêm vivas, mesmo com as mudanças alimentares existentes. Isto é a valorização das diferenças, que acompanha este processo, sugerindo o crescimento dos restaurantes étnicos, que trazem um valor agregado, no qual permite compreender as diferentes culturas.

"Tantos as viagens como os meios de comunicação massivos tornam homogêneas as pautas culturais e fazem com que a gastronomia pareça pouco diferenciada. No entanto, as diferenças existem e as possibilidades de intercâmbio se expandem" (SCHLUTER, 2003, p. 90).

A gastronomia brasileira possui heranças africanas, indígenas e do branco europeu. Ao longo dos anos, a gastronomia brasileira viveu uma grande revolução, no qual a característica principal é a oferta diversificada, que engloba uma boa amostra da gastronomia mundial. 
"No Brasil, já se projetam rotas culturais cujo eixo é a gastronomia e seu objetivo é o desenvolvimento rural” (SCHLUTER, 2003, p.75). A Rota dos Italianos é um exemplo de rota na região Sul do país.

\subsubsection{Gastronomia e turismo}

A gastronomia e o turismo são indissociáveis uma vez que se torna impossível pensar em turismo, sem prever a alimentação para curta ou longa permanência em um local.

“A gastronomia, sem dúvida, está ganhando terreno como atração tanto para residente como para turistas. Não só nutre o corpo e o espírito, mas faz parte da cultura dos povos" (SCHLUTER, 2003, p.89).

A gastronomia e o turismo se interagem de diversas maneiras. Segundo Schluter, "o uso que o turismo faz da gastronomia, determina que esta adquira cada vez mais importância para promover um destino e para captar correntes turísticas" (2003, p.69).

A gastronomia é um produto turístico, motivado pela busca do prazer através da alimentação durante suas viagens. Atualmente é possível experimentar diversos sabores, diferentes refeições oriundas de diferentes culturas em qualquer lugar do mundo.

"Cada sociedade conta com uma ampla bagagem de tradições e costumes, e o turismo vale-se delas para atrair os visitantes interessados em diferentes manifestações culturais que se observam tanto no âmbito urbano como no rural" (SCHLUTER, 2003, p.88).

Turismo cultural, e mais recentemente, o turismo gastronômico, são modalidades na qual a gastronomia está presente diretamente como produto turístico. No entanto, a gastronomia não interage com o turismo apenas como produto, mas também na economia, por meio dos empreendimentos gastronômicos, gerando emprego e renda. É necessário acrescentar que os empreendimentos gastronômicos são os que mais empregam e oferecem melhores salários no setor de turismo (ABRASEL, 2004).

Em alguns lugares do mundo, rotas gastronômicas são criadas para intensificar o turismo local. No Brasil, o turismo gastronômico está ganhando espaço no setor turístico, principalmente nos ambientes rural, resgatando a cultura e gerando uma outra fonte de renda para esta parte da população.

No campo o resgate cultural, enquanto nas cidades, a expansão do setor dos empreendimentos gastronômicos no Brasil pode ser analisada sob vários aspectos. No âmbito federal, a política do governo voltada para o turismo, tanto doméstico, quanto internacional, tem se 
intensificado nos últimos anos, contemplando no seu planejamento a valorização da culinária nacional como importante atrativo e diferencial estratégico.

Em depoimento, Walfrido dos Mares Guia, Ministro do Turismo diz:

“Assim como a nossa natureza exuberante, a diversidade da culinária é um forte atrativo do Brasil. Valorizar essa especialidade brasileira, com todas as suas variedades e sabores é uma das políticas desenvolvidas pelo Ministério do Turismo, a partir do Programa de Produção Associada ao Turismo... A divulgação do que se produz nas cozinhas do Brasil, de uma forma que o turista não resista ao desejo de saborear ingredientes e temperos e assim conhecer nossas regiões turísticas, é uma das estratégias do Programa e de seus parceiros. Nesse contexto é que surgiu a idéia do Festival Brasil Sabor, o maior evento do País para a promoção da gastronomia nacional como produto associado que agrega valor à atividade turística".

\subsection{Brasília: História, turismo e gastronomia}

\subsubsection{Contextualização da cidade de Brasília, DF}

“O passado de Brasília remonta aos idos de 1800, quando José Bonifácio, em 1820, apresentou um projeto que se intitulava Memória sobre a necessidade e meios de edificar no interior do Brasil uma nova capital” (FISBERG, 2002, p. 5).

Muitos anos depois, foi instalada a pedra fundamental do Distrito Federal, em 7 de julho 1922. Em 21 de abril de 1960 a lei da transferência da capital do Brasil para Brasília foi sancionada, inaugurando assim, a nova capital federal, caracterizada pela mescla de pessoas vinda de todas as regiões do país, participando de sua construção.

Brasília se destaca das demais cidades do país, não só por ser a capital do Brasil, mas também por fazer parte do Distrito federal. "Este é um território autônomo, que por usa vez não possui capital, sendo organizada em 19 Regiões Administrativas” (FISBERG, 2002, p.5).

“O Distrito Federal ocupa o topo do ranking no relatório das Nações Unidas sobre o Índice de Desenvolvimento Humano (IDH), com 0,844, o que corresponde ao mais alto índice do Brasil e equivale a quatro vezes o percentual exigido pela Organização Mundial da Saúde". (BRASILIA CONVENTION \& VISITORS BUREAU).

O Distrito Federal possui a maior renda per capita do país (CODEPLAN, 2004), é quase o dobro da média brasileira. Assim, Brasília aparece como a quarta cidade brasileira entre as de maior poder de consumo. 


\subsubsection{Atividades turísticas}

De acordo com o Brasília Convention \& Visitours Bureau, o turismo no Distrito Federal é caracterizado por um conjunto de atrativos turísticos dividido nos seguintes segmentos:

- Turismo Cívico e arquitetônico;

- Turismo de negócios;

- Turismo cultural;

- Turismo religioso;

- Turismo de lazer;

- Turismo Náutico;

- Turismo ecológico e rural

De acordo com a Secretaria de Estado de Turismo do governo do Distrito Federal, as viagens internacionais à Brasília são motivadas pelos negócios (45,4\%), lazer (43,3\%), Convenções $(6,7 \%)$ e outros motivos (4,6\%), sendo dos Estados Unidos da América o maior número de turistas. E o meio de transporte mais utilizado é o avião.

Nas viagens domésticas, a motivação principal são os negócios (71,4\%), seguidos de outros motivos $(14,1 \%)$, convenções $(10,9 \%)$ e lazer $(3,6 \%)$, sendo o estado de maior emissão, São Paulo.

\subsubsection{Gastronomia}

Quanto ao segmento específico de bares e restaurante, Brasília é hoje considerada o terceiro pólo gastronômico do país, fato que por si só, demonstra o elevado grau de desenvolvimento do setor (SEBRAE, 2006).

Quem vem a Brasília, dificilmente escapa de conhecer o aglomerado de empreendimentos gastronômicos destinados ao prazer de uma boa refeição.

Miscelânea de habitantes, principalmente mineiros, goianos e nordestinos, traduz-se numa variedade culinária riquíssima, que pode ser encontrada em vários restaurantes da cidade, e agora, na chamada gastronomia rural. Esta é representada por 30 chácaras e restaurantes, que enfatizam a cozinha tipicamente brasileira, privilegiando a diversidade de culturas que caracterizam do Distrito Federal (FISBERG, WEHBA e COZZOLINO, 2002). 
Alguns restaurantes de Brasília somam tradição e a qualidade da boa comida com manifestações culturais, servindo de cenário para tardes e noites de autógrafos, apresentação de poetas e atores, vernisages de pintores, lançamento de bebidas.

Outros, pela freqüência com que recebem alguns clientes, acabam fazendo história, como é o caso do Piantella, que no mezanino manteve reservada uma mesa para o falecido deputado Ulysses Guimarães e os próceres do PMDB, embora o salão continue tão democrático hoje como foi no passado, pois é lugar muito freqüentado pelos políticos de todos os partidos e também por autoridades, ministros, personalidades. E o Bar Brasília, que continua o predileto do PT mesmo depois do partido vencer as eleições. Até jornalistas têm seus redutos preferidos.

O setor de alimentos e bebidas não pára de crescer, pois os empresários encontram boas razões de investir no mercado brasiliense, farto de consumidor exigente, à altura do poder aquisitivo, um dos maiores do país.

\subsection{Marketing: Definição e ferramentas de marketing}

A evolução do marketing acompanhou o desenvolvimento econômico e empresarial no decorrer do tempo. A primeira vez que a palavra marketing foi utilizada como substantivo foi no século XX. No entanto, seu significado era associado a ações relacionadas com atividades de venda (COOPER, 2001, p.382).

O marketing é considerado um fenômeno novo. Seu conceito deve estar relacionado ao desenvolvimento de idéias.

São inúmeras as definições de marketing, muitas delas considerando apenas a promoção, sendo está uma interpretação estreita do seu conceito.

Para este estudo é utilizado o conceito de Kotler, no qual ele estabelece uma distinção entre as definições sociais e gerenciais do marketing.

Marketing social consiste em mostrar o papel do marketing na sociedade, ou seja, é um processo social por meio do qual as pessoas e grupos de pessoas obtêm aquilo que necessitam e o que desejam com a criação, oferta e livre negociação de produtos e serviços de valor com outro (KOTLER, 2000, p.30).

O marketing gerencial é geralmente definido como a arte de vender produtos, no entanto, sua função é maior que isso. Na verdade este tipo de marketing é utilizado para compreender o cliente, podendo assim, adaptar os produtos e serviços a eles, e como conseqüência, aumentar 
as vendas. Trata-se de "um processo de planejar e executar a concepção, a determinação do preço, a promoção e a distribuição das idéias, bens e serviços para criar trocas que satisfaçam metas individuais e organizacionais" (KOTLER, 2000, p.30).

Deve-se dizer que o enfoque de toda definição de marketing é a necessidade do consumidor como origem de todos os esforços da organização (COOPER, 2001, p.384).

\subsubsection{Conceitos centrais do marketing}

Para compreender melhor o marketing é necessário que se conheça seus conceitos centrais:

- Mercado alvo e segmentação: No início do planejamento de marketing é necessário segmentar o mercado, considerando a dificuldade em agradar a todos. Assim, é possível desenvolver ofertas direcionadas a determinado mercado;

- Necessidades desejos e demanda: Os profissionais de marketing precisam compreender as necessidades (exigências humanas básicas), os desejos (necessidades moldados de acordo com a sociedade em que vive) e a demanda (são desejos por produtos específicos apoiados por uma possibilidade de pagar) do seu mercado alvo (KOTLER, 2000, p.33);

- Produto ou oferta: Os produtos satisfazem as necessidades e os desejos das pessoas. Um produto é qualquer oferta que satisfaçam esses quesitos. Uma marca é uma oferta conhecida (KOTLER, 2000, p.33);

- Valor e satisfação: o valor é definido "como a razão entre o que cliente recebe e o que ele paga... o cliente recebe benefícios e paga por eles"(KOTLER, 2000, p.33);

- Troca e transações: A troca é considerada o conceito central do marketing, no qual se obtém um produto desejado de alguém em troca de algo. Já a transação envolve "pelo menos duas coisas de valor, acordo no que diz respeito às condições, momento de acordo e local de acordo" (KOTLER, 2000, p.34). O profissional de marketing é responsável por analisar cada uma das partes envolvidas na transação, a fim de realizar trocas bem sucedidas;

- Relacionamentos e redes: “O marketing de relacionamento tem como objetivo estabelecer relacionamentos mutuamente satisfatórios de longo prazo com clientes, fornecedores, distribuidores, a fim de ganhar e reter sua preferência e seus negócios" (KOTLER, 2000, p.35); 
- Necessidades dos clientes: Pode-se considerar que uma das tarefas mais difíceis para o profissional do marketing é identificar, com exatidão, as necessidades e desejos dos clientes, pois além da necessidade declarada, há uma interpretação que deve ser feita em torno dela. Assim, para a empresa, não basta apenas segmentar o mercado, a exigência é ter a percepção aguçada em relação ao seu público-alvo.

\subsubsection{O Mix de Marketing}

Segundo Kotler (2000, p.37), o mix de marketing é o conjunto de ferramentas de marketing que a empresa utiliza para atingir seus objetivos. Essas ferramentas são dividas em quatro grupos:

Produto: Habilidade para apresentar um produto que gere a satisfação, é parte integrante de um planejamento de marketing que visa o sucesso. No entanto alguns fatores devem ser considerados (COOPER, 2001, p.430):

- Qualidade: refere-se aos padrões de qualidade adotados e a implementação de um método de garantia. Isto gera uma boa reputação a empresa;

- Serviço: refere-se à criação do nível de serviço a ser oferecido para os clientes;

- Abrangência: refere à maneira como a empresa irá integrar os diferentes produtos aos que e já possui no mercado;

- Marca: Gera valor agregado ao produto, quando bem sucedida;

- Características e benefícios: refere-se as diferentes características empregadas ao produto, que podem ser catalogadas em risco reduzido e benefícios de valor agregado, com o intuito de diferencia-lo dos produtos da concorrência.

Preço: Uma característica específica do produto e envolve o custo que o cliente pretende pagar para adquirir produtos e serviços (DIAS, CASSAR, 2005, p.179). As tomadas de decisões referentes ao preço são as mais difíceis, pois há uma complexidade de fatores que se devem considerar. Aqui são considerados os descontos, concessões, prazo de pagamento e condições de financiamento.

Praça: Ponto de venda ou distribuição. Refere-se como o produto ou serviço vai estar à disposição do cliente, como vão ser entregue nos postos de venda. O planejamento do fluxo dos produtos é fundamental, e tem como análise os locais, o transporte, o estoque, as variedades, os canais e a cobertura. 
Promoção: A comunicação de marketing. Refere-se à maneira como as empresas apresentam seus produtos aos clientes, ou seja, torna-os conhecido no mercado. De acordo com Dias e Cassar (2005, p.180), esta ferramenta possibilita "o conhecimento dos benefícios oferecidos, bem como desenvolver o posicionamento da marca e do produto, ou mesmo a criação da imagem da organização e seus produtos”.

Cooper complementa (2001,p.439), que "promoção é um termo descritivo para o conjunto de atividades de comunicação que as organizações desenvolvem para influenciar os públicos dos quais suas vendas dependem".

Um dos métodos de maior relevância na promoção é a definição do seu objetivo, ou seja, definir o que a promoção deseja atingir. Desta forma, os efeitos da comunicação agirão de forma eficaz, construindo uma consciência para o produto ou serviço.

A promoção utiliza como ferramenta a promoção de venda, publicidade, força de vendas, relações públicas, marketing direto (KOTLER, 2000, p.37).

A promoção de vendas é uma ferramenta utilizada para agregar valor ao produto. São atividades que induzem um resultado desejado de clientes e equipes de venda. $\mathrm{O}$ aspecto merchandising é parte integrante da promoção de vendas, que consiste em materiais utilizados para estimular as vendas. Às vezes, a promoção de vendas é combinada com outras ferramentas de promoção com a intenção de complementar os esforços de venda (COOPER, 2001, p.441).

A propaganda, segundo Cooper (2001, p.441), "é qualquer forma de comunicação nãopessoal através da mídia que detalha um produto com um patrocinador identificado". Ela é uma forma de atingir o objetivo da empresa em relação ao produto ou serviço colocado no mercado. É necessário lembrar que "quanto mais clara e eficiente for a comunicação de marketing, mais precisa é a expectativa gerada no cliente” (DIAS, CASSAR, 2005, p.180).

As relações públicas são uma outra forma de comunicação não-pessoal que utilizam meios de comunicação de massa não pagos pela empresa, sendo seu maior atributo, melhorar a imagem da empresa.

A principal característica do marketing direto é a comunicação postal das empresas, como por exemplo, a mala-direta (COOPER, 2001, p.442).

Alguns autores como Booms e Bitner citados por Cooper (2001, p.445), acreditam que mais três Ps deviam fazer parte do mix de marketing: pessoas (comportamento, treinamento, 
atitude, incentivos, etc), percepção (ambiente, detalhes tangíveis, etc) e processo (políticas, procedimentos, envolvimento do cliente, etc).

Dias e Cassar (2005, p. 180) completa que, a promoção "não é apenas responsável somente pela clarificação das características de produtos e serviços. Por meio de técnicas comportamentais, torna-se possível influenciar a característica de consumo de um cliente".

\subsubsection{Marketing Turístico}

O marketing turístico é uma filosofia de trabalho que envolve todos e tudo dentro de uma organização pública ou privada. São todas as ações no mercado que visam captar e manter fluxos de turistas (BARRETO F., 2001).

A definição adotada por $\operatorname{Vaz}(1999$, p.18) diz que marketing turístico "é um conjunto de atividades que facilitam a realização de trocas entre os diversos agentes que atuam, direta e indiretamente, no mercado de produtos turístico". Este conceito mostra a amplitude da atividade de marketing, considerando potencialmente todo o ecossistema do mercado turístico.

O marketing turístico tem como principal função conquistar e manter clientes. Segundo Trigueiro (1999, p. 61), pesquisas comprovam que um turista satisfeito fala a três pessoas, um turista insatisfeito fala a onze. Os $96 \%$ dos turistas insatisfeitos nunca contam suas queixas e $34 \%$ dos turistas insatisfeitos não voltam ao destino turístico, preferindo outro. De acordo com este autor o que mais irrita os turistas, é ver que os responsáveis por eles não se incomodam nem dão sinal de que vão resolver seus problemas.

Trigueiro (1999, p.61) apresenta alguns lembretes, que nos ajudam a compreender melhor o que foi dito acima:

- O turista não compra produtos ou serviços, mas sim a satisfação das suas necessidades.

- O turista é alguém não um número. Ele tem rosto, nome, é gente, e deve ser tratado como tal.

- O atendimento é o valor que deve ser agregado ao produto a ser fornecido ao turista.

- Embora erros possam ser inevitáveis, turistas insatisfeitos devem ser evitáveis. 
- A lealdade ao turista é a garantia da sobrevivência da continuidade e do crescimento do turismo de uma localidade.

$\mathrm{Na}$ hora de atrair o turista, o ponto importante é a seleção de mídia, na qual deverão ser veiculadas as campanhas institucionais e promocionais do local ou empreendimento turístico. Não se pode ignorar a importância da internet nos dias atuais, tanto para divulgação de destinos e serviços oferecidos, com a praticidade que este meio de comunicação trouxe para o turismo. A internet proporcionou as agências e operadoras de viagens maior facilidade de atendimento e assim deixar o cliente mais satisfeito. 


\section{METODOLOGIA}

A palavra metodologia provém do grego e etimologicamente significa viagem que se realiza em busca de um objetivo específico. Em ciências sociais significa aceitação e avaliação de procedimentos estandardizados de acordo com a investigação que se realiza (SCHLUTER, 2003, p. 25).

Denker (1998, p.18) acrescenta que a metodologia é a maneira concreta de como se realiza a busca de conhecimento. O que fazemos para adquirir o conhecimento desejado de maneira racional e eficiente.

Neste capítulo apresentamos a metodologia empregada neste estudo, no qual foi possível obter o resultado desejado de acordo com o objetivo apresentado.

\subsection{Tipo da pesquisa}

A pesquisa consiste em um estudo descritivo e analítico das estratégias promocionais dos empreendimentos gastronômicos e a percepção de seus dirigentes com foco na atividade turística em Brasília, por meio da revisão literária e da coleta de dados.

\subsection{Método}

O método é o caminho a seguir (SCHLUTER, 2003, p. 25).

Os métodos utilizados neste estudo foram o de levantamento.

Segundo Dencker (1998, p.127), o levantamento consiste na coleta de dados referentes a uma dada população a partir da amostra selecionada dentro de critérios estatísticos. $\mathrm{O}$ levantamento usa técnicas estatísticas e análise quantitativa e permite a generalização dos resultados obtidos.

\subsection{Universo e amostra}

O universo da pesquisa foi baseado na Revista Veja Especial - O melhor da cidade 2006/ 2007, totalizando 444 empreendimentos gastronômicos.

A revista tem a proposta de um guia, ou seja, trazer ao público o que há de melhor em certa localidade. A escolha dos locais é feita por um júri selecionado pela própria revista, formado por homens e mulheres, os quais possuem diferentes profissões.

$\mathrm{Na}$ edição voltada a Brasília foram selecionados 444 empreendimento gastronômicos, os quais foram divididos em restaurantes, bares e similares. 
A justificativa da escolha do universo é dada por meio do objetivo geral, que visa analisar os empreendimentos gastronômicos em relação ao turismo.

Assim, considerou-se um universo mais próximo ao turista, ou o qual ele poderia ter fácil acesso, a revista Veja.

Veículo nacional de comunicação, a revista foi vista como importante meio de promoção da localidade através dos empreendimentos gastronômicos listrados, os quais poderiam ser os primeiros a serem visitados pelos turistas.

Preferiu-se para este estudo trabalhar com a amostra não probabilística, a qual Dencker (1998, p. 179) definiu como qualquer tipo de amostragem em que a possibilidade de escolher um determinado elemento do universo é desconhecida.

Desta maneira preferiu-se utilizar a amostra por conveniência , a qual é utilizado em pesquisas piloto para levantamento de problemas, testes e questionários (DECKER, 1998, p. 179), e a amostra por julgamento, pela qual o pesquisador seleciona o que acredita ser a melhor amostra para o estudo de determinado problema (DENCKER, 1998, p. 179).

Esta escolha se deve, principalmente, a falta de tempo suficiente para realização da pesquisa, e pela dificuldade de obter a participação dos empreendimentos gastronômicos em responder os questionários.

A amostra por conveniência e por julgamento do pesquisador foi o método escolhido para obter os dados de pesquisa. Foram escolhidos 30 empreendimentos gastronômicos na Asa Sul e Asa Norte em Brasília.

A pesquisa focou na Asa Sul e Asa Norte por serem parte do Plano Piloto e de concentrarem os principais pontos turísticos da cidade.

\subsection{Instrumento de coleta de dados}

A coleta de dados foi realizada entre 26 de fevereiro a 09 de março de 2007 mediante a utilização de questionário semi estruturado, com questões fechadas e abertas, com a finalidade de obter informações referentes às ações promocionais dos empreendimentos gastronômicos e sua relação com o setor de turismo. Também procurou-se desenhar a percepção dos dirigentes destes empreendimentos em relação ao assunto proposto.

A finalidade do questionário, segundo Dencker (1998, p. 146), é obter, de maneira sistemática e ordenada, informações sobre as variáveis que intervêm em uma investigação em relação a uma população ou amostra determinada. 
O questionário é conhecido como técnica de pesquisa de opinião. O questionário é uma lista de perguntas organizadas logicamente e é utilizado para juntar informações sobre um tema em particular (SCHLUTER, 2003, p. 107).

Os questionários foram distribuídos nos empreendimentos gastronômicos previamente selecionados pelo pesquisador,o qual procurou dividir, de maneira eqüitativa, a quantidade dada pela amostra entre a Asa Sul e a Asa norte.

Pela dificuldade de obter os questionários respondidos, preferiu-se acompanhar o preenchimento dos mesmos nos locais pré-estabelecidos, com o intuito de obter melhor qualidade na pesquisa proposta, evitando, assim, a total anulação dos resultados.

\subsection{Tratamento dos dados}

Para a análise quantitativa dos dados foram utilizadas ferramentas da estatística descritiva, por meio do uso do software SPSS, por qual obteve-se os resultados dos questionários respondidos.

\subsection{Fontes primárias e secundárias}

A OMT (Organização Mundial do Turismo) recomenda a avaliação do conhecimento nas fontes documentais a fim de garantir a evolução do processo de conhecimento (DENCKER, 1998, p. 43).

As fontes primárias são constituídas pelo material mais recente e original que não possua distribuição por esquemas predeterminados e que possa ser encontrado em revistas, informes de investigação, produções acadêmicas e livros.

Para esta pesquisa foram utilizados livros, monografias, dissertações de mestrado, textos científicos, a fim de promover a estrutura do conhecimento necessário para a realização da pesquisa de campo.

As fontes secundárias referem-se ao material conhecido e organizado segundo um esquema determinado. Podem ser: revistas de resumo, índices, bases de dados e banco de dados.

Foram feitas diversas pesquisas em bancos de dados de organizações voltadas ao turismo e gastronomia, como também no Ministério do Turismo e EMBRATUR. 


\section{APRESENTAÇÃO E ANÁLISE DOS DADOS}

Foi apresentado a 30 empreendimentos gastronômicos um questionário contendo 22 questões a fim de obter dados referentes ao objetivo geral da pesquisa.

Os dados coletados foram tabulados no software SPSS com o intuito de auxiliar na coordenação dos resultados.

Foram analisadas, separadamente, as repostas de cada questão, que são apresentadas na forma de tabela, com comentários inerentes ao objetivo da pesquisa.

\subsection{Localização dos empreendimentos gastronômicos}

A primeira questão trata-se da localização dos empreendimentos gastronômicos pesquisados. Pode-se observar que não há uma grande diferença do número de empreendimentos escolhidos para a pesquisa entre a Asa Norte e Asa Sul. Tentou-se manter um equilíbrio na escolha dos locais.

A Asa Norte representa 46,6\% da pesquisa e Asa Sul representa 53,3\%. Este resultado pode ser explicado pelo fato de a Asa Sul ter maior concentração de restaurantes, bares e similares de acordo com o universo da pesquisa

\begin{tabular}{|ll|r|r|r|}
\hline & & & $\begin{array}{c}\text { Porcetagem } \\
\text { acumulada }\end{array}$ \\
\hline Válido & Asa Norte & 14 & 46,7 & 46,7 \\
& Asa Sul & 16 & 53,3 & 100,0 \\
& Total & 30 & 100,0 & \\
\hline
\end{tabular}

Tabela 1 - Dados da localização dos empreendimentos gastronômicos

Fonte: Pesquisa de campo, 2007

\subsection{Tipificação dos empreendimentos gastronômicos}

O tipo do empreendimento gastronômico foi a segunda questão pertencente ao questionário. No universo da pesquisa encontravam-se três tipos: os restaurantes, os bares e os similares (sorveterias, lanchonetes, tapiocarias, creperias, entre outros). Era necessário defini-los, pois cada um possui características de serviços, produtos e clientes.

No total dos profissionais entrevistados, os restaurantes foram à maioria, representando $56,7 \%$ dos pesquisados, seguidos dos bares e similares. Este dado já era esperado, tendo em vista que os restaurantes eram mais da metade do universo pesquisado. 


\begin{tabular}{|ll|r|r|r|}
\hline & & & $\begin{array}{c}\text { Porccentagem } \\
\text { acumulada }\end{array}$ \\
\hline Válido & Restaurante & 17 & 56,7 & 56,7 \\
& Bar & 6 & 20,0 & 76,7 \\
& Similar & 7 & 23,3 & 100,0 \\
& Total & 30 & 100,0 & \\
\hline
\end{tabular}

Tabela 2 - Tipos de empreendimentos pesquisados

Fonte: Pesquisa de campo, 2007

4.3. Tempo de mercado dos empreendimentos gastronômicos

O tempo de mercado do empreendimento gastronômico também foi questionado, a fim de embasar a pesquisa.

Empreendimentos que estão no mercado entre 01 a 05 anos representam a parte mais expressiva dos pesquisados, com 46,7\%. Os empreendimentos entre 05 e 10 anos ficaram em segundo lugar, o qual representa $33,3 \%$ dos entrevistados.

\begin{tabular}{|ll|r|r|r|}
\hline & Frequencia & Porcentagem & $\begin{array}{c}\text { Porcentagem } \\
\text { acumulada }\end{array}$ \\
\hline Válido & Menos de 01 ano & 2 & 6,7 & 6,7 \\
& De 01 a 05 anos & 14 & 46,7 & 53,3 \\
De 05 a 10 anos & 10 & 33,3 & 86,7 \\
Outros & 4 & 13,3 & 100,0 \\
Total & 30 & 100,0 & \\
\hline
\end{tabular}

Tabela 3 - Tempo do empreendimento gastronômico no mercado Fonte: Pesquisa de campo, 2007

\subsection{A função dos dirigentes dos empreendimentos gastronômicos}

A função ocupada pelo entrevistado também fez parte do questionamento no qual foram entrevistados os proprietários, gerentes e responsáveis pelo turno.

A maioria entrevistada é representada pelos gerentes, com 53,3\%. Proprietários e responsáveis pelo turno correspondem a 23, 3\%.

\begin{tabular}{|ll|r|r|r|}
\hline & & & $\begin{array}{c}\text { Porcentagem } \\
\text { acumulada }\end{array}$ \\
\hline Válido & Proprietário & 7 & 23,3 & 23,3 \\
& Gerente & 16 & 53,3 & 76,7 \\
& Responsável pelo turno & 7 & 23,3 & 100,0 \\
& Total & 30 & 100,0 & \\
\hline
\end{tabular}

Tabela 4 - Função do entrevistado no empreendimento gastronômico Fonte: Pesquisa de campo, 2007 


\subsection{Tempo de trabalho do profissional}

O tempo de trabalho é uma variável importante na pesquisa, a fim de fundamentar as respostas recebidas. Entende-se que quanto maior o tempo de experiência na área, maior o conhecimento do mercado.

Dentre os entrevistados, a maioria é representada por pessoas que trabalham no setor de alimentação entre 01 a 05 anos, 56,7\%.

Neste ponto da pesquisa, pode-se dizer que a maioria dos entrevistados são gerentes dos empreendimentos, e que estão no mercado a mesma quantidade de tempo que a maioria dos empreendimentos entrevistados estão com as portas abertas.

É necessário observar que no setor de alimentação ainda faltam bons profissionais para ocuparem os cargos existentes.

\begin{tabular}{|ll|r|r|r|}
\hline & & & $\begin{array}{r}\text { Porcetagem } \\
\text { acumulativa }\end{array}$ \\
\hline válido & Menos de 01 ano & $\mathbf{5}$ & 16,7 & 16,7 \\
& De 01 a 05 Anos & 17 & 56,7 & 73,3 \\
& De 05 a 10 anos & $\mathbf{8}$ & 26,7 & 100,0 \\
Total & 30 & 100,0 & \\
\hline
\end{tabular}

Tabela 5 - Tempo de trabalho do entrevistado no setor de alimentação

Fonte: Pesquisa de campo, 2007

\subsection{A importância da marca do empreendimento gastronômico}

De acordo com Cooper (2001, p. 430), a marca gera valor agregado ao produto, quando bem sucedida. Esta afirmação faz parte dos fatores que constituem o estudo do "produto" no mix de marketing.

Quando foi questionado o grau de importância da marca, buscou-se saber se os dirigentes consideravam a marca como gerador de crescimento e mantedor do empreendimento.

Verificou-se que a grande maioria tem a percepção de que a marca é importante, representado $93,3 \%$ dos pesquisados.

\begin{tabular}{|ll|r|r|r|}
\hline & & Frequencia & Porcentagem & $\begin{array}{c}\text { Porcentagem } \\
\text { acumulada }\end{array}$ \\
\hline Válido & Médio & 2 & 6,7 & 6,7 \\
& Alto & 28 & 93,3 & 100,0 \\
& Total & 30 & 100,0 & \\
\hline
\end{tabular}

Tabela 6 - A importância da marca do empreendimento gastronômico Fonte: Pesquisa de campo, 2007 


\subsection{Orçamento destinado a marketing}

A definição de marketing está vinculada a desenvolvimento de idéias, a criação, a oferta, a satisfação das necessidades e desejos. Segundo Cooper (2001), deve-se dizer que o enfoque de toda definição de marketing é a necessidade do consumidor como origem de todos os esforços da organização.

Considera-se que toda empresa deve possuir uma maneira de mostrar seu produto e atrair o cliente.

O setor de alimentação está em pleno desenvolvimento no mundo. A sobrevivência, o crescimento depende do público que se deseja atingir. Para isso é necessário ter um plano de marketing que adeque a proposta do empreendimento.

Quando questionado se o marketing faz parte do orçamento do empreendimento, $86,7 \%$ dos entrevistados disseram que sim. Outros $10 \%$ que responderam negativamente, justificaram não saber se o empreendimento possui ou não tal investimento. Apenas 1 entre os 3 que responderam negativamente deu como justificativa a falta de dinheiro.

\begin{tabular}{|rr|r|r|r|}
\hline & & Frequencia & Porcentagem & $\begin{array}{c}\text { Porcentagem } \\
\text { acumulada }\end{array}$ \\
\hline Válido & & 1 & 3,3 & 3,3 \\
& Sim & 26 & 86,7 & 90,0 \\
& Não & 3 & 10,0 & 100,0 \\
& Total & 30 & 100,0 & \\
\hline
\end{tabular}

Tabela 7 - Investimento com marketing pelo empreendimento gastronômico

Fonte: Pesquisa de campo, 2007

\begin{tabular}{|c|c|c|c|}
\hline & Frequencia & Porcentagem & $\begin{array}{l}\text { Porcentagem } \\
\text { acumuladqa }\end{array}$ \\
\hline Válido & 27 & 90,0 & 90,0 \\
\hline Não sei & 1 & 3,3 & 93,3 \\
\hline Não sei dizer & 1 & 3,3 & 96,7 \\
\hline Sem dinheiro & 1 & 3,3 & 100,0 \\
\hline Total & 30 & 100,0 & \\
\hline
\end{tabular}

Tabela 8 - Justificativa de não investir em marketing

Fonte: Pesquisa de campo, 2007

\subsection{Ferramentas de marketing utilizadas}

De acordo com a pesquisa a maioria dos empreendimentos possui investimentos em marketing, assim, seria necessário definir quais as ferramentas de marketing utilizadas pelos empreendimentos. Percebeu que a maioria deles utiliza as promoções para se promoverem. 
A promoção é considerada a comunicação em marketing. Como disseram Dias e Cassar (2005, p.180), esta ferramenta possibilita o conhecimento dos benefícios oferecidos, bem como desenvolver o posicionamento da marca e do produto, ou mesmo a criação da imagem da organização e seus produtos.

Foram consideradas cinco ações promocionais para esta questão: promoção de venda, promoção interna, promoção em parceria com entidades beneficentes, promoção com propaganda e participação em feiras e exposições.

Dentre os pesquisados, $56,7 \%$ utilizam as ações promocionais com propaganda, seguidos de promoção interna, com $16,7 \%$. Promoções de venda correspondem a $10 \%$ e participação em feiras corresponde a 3,3\%. Os demais, $6,7 \%$, não responderam a questão ou indicaram como outras as ações de marketing utilizadas.

Deve-se dizer que alguns dos empreendimentos utilizam mais de uma ação promocional. Em alguns casos foram citados até 3 ações diferentes, dentre elas participações em feiras gastronômicas.

\begin{tabular}{|c|c|c|c|c|}
\hline & & Frequencia & Porcentagem & $\begin{array}{l}\text { Porcentagem } \\
\text { acumulada }\end{array}$ \\
\hline \multirow[t]{7}{*}{ válido } & & 2 & 6,7 & 6,7 \\
\hline & Promoções de Venda & 3 & 10,0 & 16,7 \\
\hline & Promoção Interna & 5 & 16,7 & 33,3 \\
\hline & $\begin{array}{l}\text { Promoção com } \\
\text { propaganda }\end{array}$ & 17 & 56,7 & 90,0 \\
\hline & $\begin{array}{l}\text { Participação em } \\
\text { feiras e exposições }\end{array}$ & 1 & 3,3 & 93,3 \\
\hline & Outros & 2 & 6,7 & 100,0 \\
\hline & Total & 30 & 100,0 & \\
\hline
\end{tabular}

Tabela 9 - As ações promocionais utilizadas pelos empreendimentos gastronômicos Fonte: Pesquisa de campo, 2007

\subsection{Resultados esperados com o marketing}

A pesquisa também procurou responder à questão sobre os resultados esperados com as ações de marketing adotadas.

É certo dizer que a maioria dos empreendimentos gastronômicos encontra-se satisfeita com os resultados obtidos, os quais são representados por $76,7 \%$ dos pesquisados. 


\begin{tabular}{|ll|r|r|r|}
\hline & Frequencia & Porcentagem & $\begin{array}{c}\text { Porcentagem } \\
\text { acumulada }\end{array}$ \\
\hline válido & 2 & 6,7 & 6,7 \\
& Sim & 23 & 76,7 & 83,3 \\
& Poderia ser melhor & 5 & 16,7 & 100,0 \\
\multicolumn{2}{|c|}{ Total } & 30 & 100,0 & \\
\hline
\end{tabular}

Tabela 10 - Resultados esperados com as ações de marketing são alcançados

Fonte: Pesquisa de campo, 2007

\subsection{Pesquisa de satisfação do cliente}

É necessário que além de utilizar as ações de marketing para atrair o cliente, seja feita pesquisa periódica da satisfação dos clientes. Isto auxilia na determinação da escolha das ações promocionais, além de saber se o investimento é coerente.

A maioria dos entrevistados diz fazer pesquisas de satisfação do cliente e representa $53,3 \%$ dos pesquisados.

Em muitos restaurantes encontram-se cartões à mesa para que o cliente possa opinar sobre o que percebeu de bom ou ruim no local. Outras empresas enviam correspondências a clientes cadastrados a fim de buscarem informações sobre o eles acham do empreendimento. Verificar na tabela 12 .

Mas, percebe-se que o meio mais utilizado para obter informações dos clientes, são as conversas informais durante o atendimento.

Pode-se considerar uma forma de avaliar a satisfação, mas não se deve desconsiderar o fato de ela não ser exata e, às vezes, representativa, pois não se sabe como isso é tabulado em dados para as empresas.

\begin{tabular}{|c|c|c|c|c|}
\hline & & Frequencia & Porcentagem & $\begin{array}{l}\text { Porcentagem } \\
\text { acumuluda }\end{array}$ \\
\hline \multirow[t]{4}{*}{ Válido } & & 1 & 3,3 & 3,3 \\
\hline & Sim & 16 & 53,3 & 56,7 \\
\hline & Não & 13 & 43,3 & 100,0 \\
\hline & Total & 30 & 100,0 & \\
\hline
\end{tabular}

Tabela 11 - Pesquisa de satisfação do cliente nos empreendimentos gastronômicos Fonte: Pesquisa de campo, 2007 


\begin{tabular}{|c|c|c|c|c|}
\hline & & Frequencia & Porcentagem & $\begin{array}{l}\text { Porcentagem } \\
\text { acumulada }\end{array}$ \\
\hline \multirow[t]{10}{*}{ Válido } & & 18 & 60,0 & 60,0 \\
\hline & $\begin{array}{l}\text { No atendimento ao } \\
\text { cliente }\end{array}$ & 1 & 3,3 & 63,3 \\
\hline & Avaliações a mesa & 1 & 3,3 & 66,7 \\
\hline & Catão de satisfação & 1 & 3,3 & 70,0 \\
\hline & Conversa com cliente & 2 & 6,7 & 76,7 \\
\hline & Conversa com o cliente & 2 & 6,7 & 83,3 \\
\hline & Conversas com cliente & 1 & 3,3 & 86,7 \\
\hline & Direto com o cliente & 1 & 3,3 & 90,0 \\
\hline & Mala direta & 3 & 10,0 & 100,0 \\
\hline & Total & 30 & 100,0 & \\
\hline
\end{tabular}

Tabela 12 - Como é realizada a pesquisa de satisfação do cliente Fonte: Pesquisa de campo, 2007

\subsection{Entendimento sobre o turismo}

De acordo com Otto (2001, p. 19), não há uma definição única do que seja turismo, ela se transforma de acordo com as necessidades humanas, assim sua definição torna-se dinâmica e surge de acordo com o comportamento sócio-cultural e econômico da humanidade.

Durante a pesquisa procurou-se saber qual a percepção dos dirigentes dos empreendimentos gastronômicos em relação ao turismo, parte do objetivo geral da pesquisa.

Verificou-se que a parte mais expressiva dos dirigentes, cerca de 30\% dos entrevistados, compreende o turismo como viagem, lazer, interação entre as pessoas e geração de renda.

Isto significa que a visão dos dirigentes dos empreendimentos em relação ao turismo é abrangente e oportunista, ponto positivo para esta pesquisa.

\begin{tabular}{|l|r|r|r|}
\hline & Frequencia & Porcentagem & $\begin{array}{c}\text { Porcentagem } \\
\text { acumulada }\end{array}$ \\
\hline Válido & 6 & 20,0 & 20,0 \\
$\begin{array}{l}\text { Viagem } \\
\text { Viagem lazer, interação } \\
\text { entre as pessoas }\end{array}$ & 8 & 26,7 & 46,7 \\
$\begin{array}{l}\text { Viagem, lazer, interação } \\
\text { entre as pessoas, } \\
\text { geração de renda } \\
\begin{array}{l}\text { Viagem, lazer, cultura, } \\
\text { interação entre as } \\
\text { pessoas, ger. ren } \\
\text { Total }\end{array}\end{array} \quad 9$ & 30,0 & 76,7 \\
\hline
\end{tabular}

Tabela 13 - Entendimento de turismo

Fonte: Pesquisa de campo, 2007 
4.12. Benefícios que o turismo proporciona à cidade de Brasília

É certo dizer que o turismo vem se destacando na economia mundial, principalmente por se tratar de um setor que abrange uma variedade de elementos necessários para a realização da atividade turística. Os transportes, os alojamentos, o comércio, as atrações, a cultura local, são exemplos de alguns desses elementos.

O turismo é negócio, geração de renda e empregos. Trata-se de uma atividade econômica que pertence ao setor terciário.

Devido ao seu desenvolvimento e maior acessibilidade, cada vez mais pessoas em todo mundo encontram nas viagens a melhor alternativa para preencher seu tempo livre.

Diante do exposto, pode-se dizer que o turismo tende a proporcionar benefícios aos locais onde atua, desde que seja planejado e consciente.

Foi perguntado aos dirigentes dos empreendimentos gastronômicos, se eles acreditavam que o turismo proporciona benefícios a Brasília. A maior parte dos entrevistados, 96,7\%, acredita que o turismo beneficia o município, principalmente, gerando renda e emprego a população.

\begin{tabular}{|ll|r|r|r|}
\hline & & Frequencia & Porcentagem & $\begin{array}{c}\text { Porcentagem } \\
\text { acumulada }\end{array}$ \\
\hline Válido & & 1 & 3,3 & 3,3 \\
& Sim & 29 & 96,7 & 100,0 \\
& Total & 30 & 100,0 & \\
\hline
\end{tabular}

Tabela 14- Benefícios que o turismo proporciona à cidade Fonte: Pesquisa de campo, 2007 


\begin{tabular}{|c|c|c|c|c|}
\hline & & Frequencia & Porcentagem & $\begin{array}{l}\text { Porcentagem } \\
\text { acumulativa }\end{array}$ \\
\hline \multirow[t]{21}{*}{ Válido } & & 6 & 20,0 & 20,0 \\
\hline & De forma econômica & 1 & 3,3 & 23,3 \\
\hline & Dinheiro & 1 & 3,3 & 26,7 \\
\hline & Emprego & 1 & 3,3 & 30,0 \\
\hline & Eventos, promoção & 1 & 3,3 & 33,3 \\
\hline & Geração de emprego & 1 & 3,3 & 36,7 \\
\hline & Geração de emprego & 1 & 3,3 & 40,0 \\
\hline & Geração de emprego e renda & 1 & 3,3 & 43,3 \\
\hline & Geração de renda & 1 & 3,3 & 46,7 \\
\hline & Geração de renda & 1 & 3,3 & 50,0 \\
\hline & Geração de renda & 1 & 3,3 & 53,3 \\
\hline & Maior renda & 1 & 3,3 & 56,7 \\
\hline & melhora a renda & 1 & 3,3 & 60,0 \\
\hline & Melhora o fluxo de pessoas & 1 & 3,3 & 63,3 \\
\hline & Muito. Tur. Executiv & 1 & 3,3 & 66,7 \\
\hline & Promoção, geração de renda & 1 & 3,3 & 70,0 \\
\hline & Renda & 5 & 16,7 & 86,7 \\
\hline & Renda/ emprego & 1 & 3,3 & 90,0 \\
\hline & Trabalho & 2 & 6,7 & 96,7 \\
\hline & Turismo executivo & 1 & 3,3 & 100,0 \\
\hline & Total & 30 & 100,0 & \\
\hline
\end{tabular}

Tabela 15 - Lista de benefícios que o turismo proporcionam a cidade Fonte: Pesquisa de campo, 2007

\subsection{Relacionamento entre turismo e gastronomia}

A gastronomia e o turismo interagem de diversas maneiras. De acordo com Schluter (2203), o uso que o turismo faz da gastronomia, determina que esta adquira cada vez mais importância para promover um destino e para captar correntes turísticas.

O turismo cultural, e mais recente, o turismo gastronômico, são modalidades nas quais a gastronomia é um produto turístico. No entanto, a gastronomia não interage com o turismo apenas como produto, mas também na economia, por meio dos empreendimentos gastronômicos, como gerador de emprego e renda.

Brasília é o terceiro pólo gastronômico do país, caracterizado por sua diversidade atribuída, por meio de seus imigrantes desde sua fundação. A atividade turística encontra-se em expansão, o turismo de eventos, de negócios, o ecoturismo, o turismo cívico, são algumas das modalidades que encontramos na cidade. 
A partir destas informações, decidiu-se que era importante saber se os dirigentes dos empreendimentos gastronômicos consideravam o relacionamento entre o turismo e a gastronomia.

Grande parte dos entrevistados, cerca de 93,3\%, responderam que há um relacionamento entre o turismo e gastronomia. Apenas 3,3\% responderam negativamente, e outros 3,3\% não souberam responder.

\begin{tabular}{|rr|r|r|r|}
\hline & & Frequencia & Porcentagem & $\begin{array}{c}\text { Porcentagem } \\
\text { acumulada }\end{array}$ \\
\hline Válido & & 1 & 3,3 & 3,3 \\
& Sim & 28 & 93,3 & 96,7 \\
& Não & 1 & 3,3 & 100,0 \\
& Total & 30 & 100,0 & \\
\hline
\end{tabular}

Tabela 16 - Relacionamento turismo $X$ gastronomia

Fonte: pesquisa de campo, 2007

4.14. Benefícios que o turismo proporciona aos empreendimentos gastronômicos

Depois de questionado o relacionamento entre o turismo e a gastronomia, era necessário saber se os dirigentes acreditam que o turismo proporciona benefícios aos empreendimentos gastronômicos.

Verificou-se que $80 \%$ acreditam que o turismo proporciona benefícios aos empreendimentos, principalmente, no que tange em atrair visitantes, ou seja, mais consumidores.

Os entrevistados que responderam negativamente, cerca de $16,7 \%$, afirmaram não ter conhecimento se seus consumidores são turistas, mas acreditam que a maioria é moradora da cidade de Brasília.

\begin{tabular}{|c|c|c|c|c|}
\hline & & Frequencia & Porcentagem & $\begin{array}{c}\text { Porcentagem } \\
\text { acumulada }\end{array}$ \\
\hline \multirow[t]{4}{*}{ Válido } & & 1 & 3,3 & 3,3 \\
\hline & Sim & 24 & 80,0 & 83,3 \\
\hline & Não & 5 & 16,7 & 100,0 \\
\hline & Total & 30 & 100,0 & \\
\hline
\end{tabular}

Tabela 17 - Turismo proporciona benefícios aos empreendimentos gastronômicos Fonte: Pesquisa de campo, 2007

4.15. Os benefícios que os empreendimentos gastronômicos proporcionam ao turismo

Dos entrevistados, 96,7\% disseram acreditar que os empreendimentos gastronômicos beneficiam o turismo. 
Como disse Schluter,(2003, p. 88) "cada sociedade conta com uma ampla bagagem de tradições e costumes, e o turismo vale-se delas para atrair visitantes".

Além de atrair visitantes, os empreendimentos gastronômicos são os que mais geram emprego e oferecem os melhores salários no setor de turismo (ABRASEL, 2004). Isto, para a economia e sociedade local, é um grande benefício.

\begin{tabular}{|lr|r|r|r|}
\hline & & Frequencia & Porcentagem & $\begin{array}{c}\text { Porcentagem } \\
\text { acumulada }\end{array}$ \\
\hline Válido & & 1 & 3,3 & 3,3 \\
& Sim & 29 & 96,7 & 100,0 \\
& Total & 30 & 100,0 & \\
\hline
\end{tabular}

Tabela 18 - Empreendimentos gastronômicos proporciona benefícios ao turismo Fonte: Pesquisa de campo, 2007

\subsection{Promoção por meio das atividades turísticas}

Levando em conta que as ações promocionais podem ser implementadas com foco na interação dos empreendimentos gastronômicos no setor turístico, a pesquisa indicou que nos dias atuais isso não é feito.

Cerca de $70 \%$ dos entrevistados responderam não utilizar as atividades turísticas para se promoverem. Já 23\% dos entrevistados disseram que promovem seus empreendimentos junto ao setor turístico, principalmente, por estarem localizados em hotéis e por meio de participações em feiras e eventos.

\begin{tabular}{|c|c|c|c|c|}
\hline & & Frequencia & Porcentagem & $\begin{array}{l}\text { Porcentagem } \\
\text { acumulativa }\end{array}$ \\
\hline \multirow[t]{4}{*}{ válido } & & 2 & 6,7 & 6,7 \\
\hline & Sim & 7 & 23,3 & 30,0 \\
\hline & Não & 21 & 70,0 & 100,0 \\
\hline & Total & 30 & 100,0 & \\
\hline
\end{tabular}

Tabela 19 - Empreendimentos gastronômicos utilizam das atividades turísticas para se promoverem

Fonte: Pesquisa de campo, 2007

\subsection{Participação no Festival gastronômico, 2006}

O festival gastronômico, Brasil Sabor, realizado em 2006 pela ABRASEL em parceria com Ministério do Turismo e SEBRAE envolveu, simultaneamente, 1.057 restaurantes, em 70 cidades e 24 estados brasileiros. O festival ocorreu nas capitais dos Estados participantes. 
Foi um evento inédito para a gastronomia brasileira, o qual possibilitou os empreendimentos gastronômicos se promoverem em todos o país.

O Objetivo do evento foi demonstrar que além dos seus atraentes destinos turísticos, o Brasil possui uma gastronomia muito rica. E assim, comprovar que com toda a variedade de ingredientes encontrada no Brasil, a culinária brasileira é um grande diferencial competitivo para o turismo do país.

Em Brasília, dos 30 empreendimentos entrevistados, 14 deles participaram do Festival, o que representa $46,7 \%$ do total. Dentro do universo escolhido, este resultado não é considerado ruim, o que representa que os empreendimentos em Brasília estão abertos à nova forma de promoção junto as atividades turísticas, principalmente em eventos.

\begin{tabular}{|c|c|c|c|c|}
\hline & & Frequencia & Porcentagem & $\begin{array}{l}\text { Porcentagem } \\
\text { acumulada }\end{array}$ \\
\hline válido & & 1 & 3,3 & 3,3 \\
\hline & Sim & 14 & 46,7 & 50,0 \\
\hline & Não & 15 & 50,0 & 100,0 \\
\hline & Total & 30 & 100,0 & \\
\hline
\end{tabular}

Tabela 20 - Participação no Festival gastronômico/ 2006

Fonte: Pesquisa de campo, 2007

\subsection{Interesse na promoção junto a atividades turísticas}

Quando questionados se teriam interesse em promover os empreendimentos gastronômicos juntos com as atividades turísticas existentes, a maioria dos dirigentes, 70\%, disse que sim. Apenas 23,3\% disseram não ter interesse, e os outros 6,7\% não responderam.

Assim, é possível dizer que os empreendimentos gastronômicos da cidade têm interesse em buscar nas atividades turísticas um meio de promoção, embora não tenham dito de que forma isso seria feito.

\begin{tabular}{|c|c|c|c|c|}
\hline & & Frequencia & Porcentagem & $\begin{array}{l}\text { Porcentagem } \\
\text { acumulada }\end{array}$ \\
\hline \multirow[t]{4}{*}{ Válido } & & 2 & 6,7 & 6,7 \\
\hline & Sim & 21 & 70,0 & 76,7 \\
\hline & Não & 7 & 23,3 & 100,0 \\
\hline & Total & 30 & 100,0 & \\
\hline
\end{tabular}
turísticas

Tabela 21 - Interesse do empreendimento gastronômico em promover-se junto as atividades

Fonte: Pesquisa de campo, 2007

Após a apresentação e análise dos dados é certo dizer que os objetivos específicos foram alcançados, o que possibilitou o objetivo geral da pesquisa ser enfático no que se propôs. 
Explicar o relacionamento entre turismo e gastronomia e descrever o que é produto turístico e como a gastronomia está inserida no contexto, faz parte do referencial teórico da pesquisa, que se baseou em livros, trabalhos acadêmicos e textos científico para tal compreensão.

Não foi possível obter os dados sócios econômicos do papel dos empreendimentos gastronômicos no setor de turismo em Brasília, pois não há dados estatísticos que destaquem este relacionamento.

Verificou-se as estratégias promocionais dos empreendimentos gastronômicos, as quais poucas ou nenhumas são direcionadas ao turismo. Apenas a participação no festival gastronômico - Brasil Sabor foi citado como meio de promoção relacionado ao setor do turismo.

A percepção dos dirigentes no que tange o relacionamento entre o turismo e os empreendimentos gastronômicos é positiva, de maneira que maioria acredita que ambos se relacionam e que trazem benefícios às partes envolvidas e a população da cidade.

Algumas estratégias promocionais poderiam ser propostas aos empreendimentos gastronômicos para poderem usufruir as atividades turísticas de Brasília como meio de promoção, como:

- Unir-se a agências de viagens e operadoras turísticas, no qual seria oferecido um almoço ou jantar no empreendimento, juntamente com o pacote vendido.

- Realizar promoções de venda que atrairia o turista. Estas promoções poderiam estar interligadas a hotelaria local, aos passeios oferecidos, aos eventos realizados.

- Promover propagandas em locais turísticos: monumentos, centro de convenções, parques da cidade, região hoteleira. 


\section{CONSIDERAÇÕES FINAIS}

Este estudo teve como foco a cidade de Brasília, principalmente o Plano Piloto, Asa Sul e Asa Norte, área esta norteada de atrativos, história e monumentos, os quais atraem visitantes de toda parte do país e do mundo.

É expressiva a quantidade de empreendimentos gastronômicos localizados na área pesquisada. Variedade é a característica principal. Os tipos e tamanho remonta um espaço adequado para todos os gostos. Pode-se dizer que Brasília oferece uma gama oferta de restaurantes, bares e similares, considerada assim, o terceiro pólo gastronômico do país.

Este estudo teve como objetivo a análise das estratégias promocionais dos empreendimentos gastronômicos e a percepção de seus dirigentes com foco na atividade turística em Brasília. Os dados coletados permitiram evidenciar a importância do turismo e dos empreendimentos gastronômicos na cidade em relacionar-se, e a forma como interagem com o intuito de promover-se.

Dentre os tipos de empreendimentos gastronômicos encontrados na Asa Sul e Norte em Brasília, os restaurantes são a grande maioria.

O tempo de mercado da maioria dos empreendimentos entrevistados oscila entre um a cinco anos, tempo este considerado de crescimento, transformação e maturação dos negócios. $\mathrm{O}$ mesmo pode-se dizer de seus dirigentes, os quais estão no mercado no mesmo período de tempo.

No entanto, é o papel destes dirigentes que impulsiona o crescimento dos empreendimentos no mercado. Assim pode-se afirmar que a qualidade do elemento humano é uma necessidade prioritária, já que a excelência do serviço depende de como este elemento está interagindo com meio (mercado, cliente, fornecedores, entre outros).

Em relação ao marketing, percebeu-se que há muito por fazer. Investimentos são realizados, mas muitas vezes de forma ineficaz. Ineficaz, não pelos resultados esperados, e sim por não saber o que esperar, ou seja, aonde chegar. Durante a pesquisa ficou evidente a insegurança das respostas de alguns entrevistados, o que demonstra a falta de preparo dos mesmos.

A percepção do que é marketing para os dirigentes é restrito. A pesquisa demonstra que os entrevistados consideraram a marca e as ações promocionais importante para o empreendimento gastronômico, mesmo não compreendidas totalmente por todos. 
No que tange ao investimento com marketing, a promoção com propaganda (anúncios, folhetos, outdoor, mídia, fotos, entre outros) é a mais utilizada pelos empreendimentos gastronômicos. Participações em feiras também foram citadas como forma de promoção, sendo um exemplo da interação entre ambos os setores.

Concluiu-se que a percepção dos dirigentes, no que se refere ao turismo é abrangente. Considerou-se a atividade turística e os benéficos que ela proporciona a cidade (geração de emprego e renda, melhoria da infra-estrutura) e, não apenas seu lado lúdico, como forma de aproveitar seus momentos de lazer.

Em se tratando de marketing, poucos utilizam as atividades turísticas para se promoverem, mas muitos enxergam a possibilidade disso acontecer. A forma como poderia ser realizada esta promoção não foi informada durante a pesquisa. A minoria entrevistada deu sugestões de como promoveriam seu empreendimento com o turismo.

A forma de promoção citada, e por alguns empreendimentos utilizados, considerando a atividade turística, é a participação no Festival Gastronômico - Sabor Brasil, realizado pela ABRASEL, SEBRAE e Ministério do Turismo. Outros empreendimentos, por estarem localizados em hotéis, consideram que assim, promovam-se por meio do turismo, o que já significa um primeiro passo, mas não o suficiente.

Os dirigentes, na sua maioria, acreditam que o turismo e gastronomia se relacionam. Os benéficos mútuos foram citados pelos entrevistados, os quais acreditam que o mercado tende a progredir com a interação entre eles.

Por fim, pode-se afirmar que a percepção dos dirigentes dos empreendimentos gastronômicos é positiva em relação ao turismo, no entanto falta o conhecimento e dados concretos sobre o relacionamento estudado.

O conhecimento é algo que se adquire. As organizações competentes de ambos os setores tem como papel fornecer subsídios para que isso ocorra. O que se vê é a falta de informações, o que traduz em falta de investimento. Dados estatísticos sobre turismo e gastronomia dificilmente são encontrados.

Contudo, algumas estratégias promocionais poderiam ser propostas aos empreendimentos gastronômicos para poderem usufruir as atividades turísticas de Brasília como meio de promoção, como: 
- Unir-se a agências de viagens e operadoras turísticas, no qual seria oferecido um almoço ou jantar no empreendimento, juntamente com o pacote vendido.

- Realizar promoções de venda que atrairia o turista. Estas promoções poderiam estar interligadas a hotelaria local, aos passeios oferecidos, aos eventos realizados.

- Promover propagandas em locais turísticos: monumentos, centro de convenções, parques da cidade, região hoteleira.

Como afirma Percival Maricato em seu livro Marketing para bares e restaurantes (2005): “O fato é que o empresário deve fazer tudo o que é racional e está ao seu alcance para abrir uma casa que ofereça a melhor relação custo e benefício para o seu cliente. Se não é garantia, isso é o que pode ser feito, no mínimo, para alcançar e merecer o sucesso". 


\section{REFERÊNCIAS}

ABRASEL. Uma questão para empresários e consumidores. Disponível em: www.abrasel.com.br. Acesso em: 10 ago 2006.

ANDRADE, José Vicente de. Turismo: fundamentos e dimensões, 2.ed., São Paulo: Ática, 1995.

AZAMBUJA. Marcelo. A gastronomia como produto turístico. In: CASTROGIOVANNI, Antonio Carlos (org). Turismo urbano. São Paulo: Contexto, 2001.

Barreto, Margarita. Manual de iniciação ao estudo do turismo. 6.ed., Campinas: Papirus, 1999.

BELTRÃO, Otto di. Turismo: a indústria do século XXI. Osasco: Editora Novo Século, 2001 .

CAMPOS, Menescal, GONÇALVES, Maria Helena B. Introdução a turismo e hotelaria. Rio de Janeiro: SENAC, 1998.

CONVENTION \& VISITORS BUREAU, Brasília. Dados gerais sobre Brasília. Disponível em:http://www.brasiliaconvention.com.br/brasilia_dados.htm. Acesso em: 25 out 06.

. Tipos de turismo em Brasília. Disponível em:

http://www.brasiliaconvention.com.br/turismo gastronomia.htm. Acesso em 25 out 06.

COOPER, Chris et al. Turismo, princípios e práticas. 2.ed. Porto Alegre: Bookman, 2001.

DIAS, Reinaldo e CASSAR, Maurício. Fundamentos do marketing turístico. São Paulo: Person Prentice Hall, 2005.

DENKER, Regina G. Métodos e técnicas de pesquisa em turismo. São Paulo: Futura, 1998. FISBERG, Mauro, WEHBA, Jamal, COZZOLINO, S. M. F. Um, dois, feijão com arroz: alimentação no Brasil de Norte a Sul. São Paulo: Editora Atheneu, 2002.

JORNAL DO COMÉRCIO. Parceria é chave para o desenvolvimento. Disponível em: www.jcrs.uol.com.br. Acesso em: 20 out 2006.

JORNAL GAZETA MERCANTIL. Orçamento do setor permite modernização de aeroportos. Disponível em: www.gazetamercantil.com.br. Acesso em:16 out 2006.

KOTLER, Philip. Administração de marketing: a edição do novo milênio. 10.ed. São Paulo: Prentice Hall, 2000. 
MARICATO, Percival. Marketing para bares e restaurantes. Rio de Janeiro: Senac Nacional, 2005.

MIDDLETON, Victor T. C. Marketing de turismo: teoria e prática. Rio de janeiro: Campus, 2002.

O guia de Brasília. Gastronomia. Disponível em: http://www.guiabsb.com.br/brasilia/resultado_pesquisa.asp?idCategoriaServico=182\&Catego

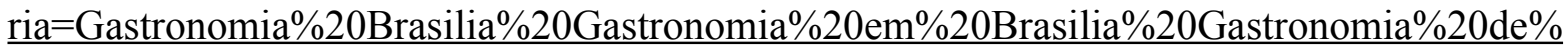
20Brasilia. Acesso em: 18 out 2006.

OLIVEIRA, Antônio Pereira. Turismo e desenvolvimento - Planejamento e organização. 3.ed., São Paulo: Atlas, 2001

PINTO J., Francisco M. Roteiros do Brasil. Rio de Janeiro: CJD Edições e Propaganda LTDA, 2005.

WILLE, Sorahia. Como viabilizar melhorias no mercado turístico brasileiro. Disponível em: http://revistaturismo.cidadeinternet.com.br/artigos/viabilizarsohaia.html. Acesso em: 01 nov 2006.

SCHLUTER, Regina G. Gastronomia e turismo. São Paulo: Aleph, 2003.

Metodologia da pesquisa em turismo e hotelaria. São Paulo: Aleph, 2003.

Secretaria de Estado de Turismo - SETUR. Atrativos Turísticos do. Disponível em: www.setur.df.gov.br. Acesso em: 23 ago 2006.

TRIGUEIRO, Carlos Meira. Marketing \& Turismo: como planejar e administrar o marketing turístico para uma localidade. Rio de Janeiro: Qualiymark, 1999.

Turismo Informativo, seu portal de turismo. Programa de Regionalização do turismo Roteiros do Brasil. Disponível em: http://www.turismoinformativo.com.br/mtstatic/archives/000293.html. Acesso em: 02 set 2006.

VAZ, Gio Nuno. Marketing turístico: receptivo e emissivo: um roteiro estratégico para projetos mercadológicos públicos e privados. São Paulo: Pioneira, 1999.

World Travel \& Tourism Concil - WTTC. Blueprint for new tourism. Disponível em: http://www.wttc.org/frameset1.htm. Acesso em: 30 out 2006. 


\section{APÊNDICE A - Questionário de pesquisa de campo}

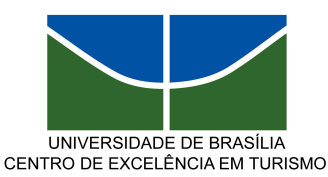

A aplicação desta pesquisa tem o intuito de buscar dados referentes às ações promocionais e a percepção dos dirigentes dos estabelecimentos gastronômicos em relação ao setor de turismo.

Os dados obtidos serão utilizados na finalização da monografia para a conclusão do curso de pósgraduação em Gestão de Negócios em Turismo, no Centro de Excelência em Turismo - CET/ UNB.

A sua participação é extremamente importante para a realização do trabalho proposto.

Agradeço desde já sua atenção.

1- Localização do estabelecimento gastronômico

( ) Asa Norte

( ) Asa Sul

2- Qual o tipo do empreendimento gastronômico?

( ) A. Restaurante

( ) B. Bar

( ) C. Similar

3- No caso de restaurante, qual é sua especialidade?

( ) A .Cozinha brasileira. Qual?

( ) B. Cozinha internacional. Qual?

( ) C. Cozinha natural.

( ) D. Fast food.

( ) E. Restaurante a quilo.

( ) F. Pizzaria.

( ) G. Variado.

4- No caso de bar, qual seu ramo de atuação?

( ) A .Boteco.

( ) B. Choperia.

( ) C. Cachaçaria.

( ) D. Variado. 
5- No caso de similar, qual é a sua especialidade?
( ) A .Cafeteria.
( ) B. Delicatessen.
( ) C. Creperia.
( ) D. Pastelaria.
( ) E. Sorveteria.
( ) F. Lanchonete.
( ) G. Casa de chá.
( ) H. Tapiocaria.
( ) I. Variado.

6- Quanto tempo que o empreendimento gastronômico está no mercado?

( ) A .Menos de 01 (um) ano.

( ) B. De 01 (um) a 05 (cinco) anos.

( ) C. De 05 (cinco) a 10 (dez) anos.

( ) D. Outros. Quanto tempo?

7- Qual a sua função neste empreendimento?

( ) A .Proprietário.

( ) B. Gerente.

( ) C. Responsável pelo turno (encarregado, supervisor).

8- Quanto tempo trabalha no setor de alimentação?
( ) A.Menos de 01(um) ano.
( ) B. De 01 (um) a 05 (cinco) anos.
( ) C. De 05 (cinco) a 10 (dez) anos.
( ) D. Outros. Quanto tempo?

9- A marca, nome comercial e fantasia são importantes para a atividade econômica. Ela identifica, posiciona, comunica, transmite segurança, reforça a imagem, etc. Para o empreendimento gastronômico, qual o grau de importância da marca?
( ) A .Baixo.
( ) B. Médio.
( ) C. Alto. 
10- Investimentos com marketing fazem parte do orçamento anual do empreendimento?
( ) A.Sim.
( ) B. Não.

Caso a resposta seja negativa. Por quê?

11- Quais as ações promocionais (conjunto de atividades que visam a fortalecer a imagem de uma marca, etc., ou influenciar pessoas na escolha de determinado produto ou serviço) utilizadas pelo restaurante?

( ) A .Promoções de venda - oferta de algo mais que o produto (brindes, descontos, degustações, entrega grátis, entre outras).

( ) B. Promoção interna - voltada à equipe (incentivos para melhorar as vendas).

( ) C. Promoção em parcerias com entidades beneficentes (solidariedade).

( ) D. Promoção com propaganda (anúncios, folheto, outdoor, mídia, mala direta, vitrine e foto, faixa, cinema, entre outros).

( ) E. Participação em feiras ou exposições.

( ) F. Outros. Qual?

12- Os resultados esperados são alcançados por meio das ações promocionais utilizadas?
( ) A.Sim.
( ) B. Não.
( ) C. Poderia ser melhor.nm

13- São feitas pesquisas periódicas em relação à motivação e a satisfação do cliente?

( ) A. Sim. Como?

( ) B. Não.

14- O que você entende por turismo?

( ) A .Viagem.

( ) B. Viagem, lazer, interação entre as pessoas.

( ) C. Viagem, lazer, interação entre as pessoas, geração de renda.

( ) D. Viagem, lazer, cultura, interação entre as pessoas, geração de renda.

( ) E. Outros. Citar:

15- Na sua opinião, a atividade turística em Brasília beneficia a cidade de alguma forma?

( ) A.Sim.

( ) B. Não.

Em caso de resposta positiva, como? 
16- Você acha que turismo e gastronomia se relacionam?

( ) A.Sim.

( ) B. Não.

Caso a resposta seja negativa. Por quê?

Caso a resposta seja positiva. Por quê?

17- No seu ponto de vista, o turismo proporciona benefícios para os empreendimentos gastronômicos?

( ) A.Sim.

( ) B. Não.

Em caso de resposta positiva, cite algum:

Em caso de resposta negativa, por quê?

18- No seu ponto de vista, os empreendimentos gastronômicos proporcionam benefícios para o turismo?

( ) A .Sim.

( ) B. Não.

Em caso de resposta positiva, cite algum:

Em caso de resposta negativa, por quê?

19- O empreendimento gastronômico utiliza as atividades turísticas da cidade de Brasília para se promover?

( ) A .Sim. Como?

( ) B. Não.

20- O estabelecimento gastronômico participou do Festival Gastronômico, realizado pela ABRASEL, ocorrido entre março e abril na cidade de Brasília, e em outra capitais?

( ) A. Sim.

( ) B. Não.

Caso a resposta seja positiva, justifique a participação:

21- É de seu interesse promover seu empreendimento junto ao setor de turismo?

( ) A.Sim.

( ) B. Não.

Em caso de resposta afirmativa, de alguma sugestão de como isto poderia ser realizado:

Em caso de resposta negativa, justifique: 
22- A atividade turística em Brasília auxilia no mantimento e/ou crescimento do estabelecimento gastronômico? Você possui algum dado oficial dos órgãos ou associações que mostre esta relação.Cite: 